\title{
AGNANO
}

\section{Evidence-Based Clinical Use of Nanoscale Extracellular Vesicles in Nanomedicine}

Stefano Fais, ${ }^{* \dagger}{ }^{\dagger}$ Lorraine O’Driscoll, ${ }^{\ddagger}$ Francesc E. Borras, ${ }^{\S}$ Edit Buzas, ${ }^{\|}$Giovanni Camussi, ${ }^{\perp}$ Francesco Cappello, Joana Carvalho, ${ }^{\text {I, } \triangle}$ Anabela Cordeiro da Silva, ${ }^{\mathrm{I}}, \boldsymbol{\Lambda}, \boldsymbol{\nabla}{ }^{\nabla}$ Hernando Del Portillo, Samir El Andaloussi, ${ }^{\triangleright}$ Tanja Ficko Trček, ${ }^{\square}$ Roberto Furlan, $^{\square}$ An Hendrix, ${ }^{\bigcirc}$ Ihsan Gursel, $^{\ominus}$ Veronika Kralj-Iglic, Bertrand Kaeffer, ${ }^{\nabla}$ Maja Kosanovic, ${ }^{\varnothing}$ Marilena E. Lekka, ${ }^{\$}$ Georg Lipps, ${ }^{\&}$ Mariantonia Logozzi, ${ }^{\dagger}$ Antonio Marcilla, $\iint, \otimes$ Marei Sammar, ${ }^{\varnothing}$ Alicia Llorente, ${ }^{\infty}$ Irina Nazarenko, ${ }^{@}$ Carla Oliveira, ${ }^{\mathbb{I}, ~} \triangle, \dagger+$ Gabriella Pocsfalvi, ${ }^{\text {*t }}$ Lawrence Rajendran, ${ }^{\S \S}$ Graça Raposo, ${ }^{\perp \perp}$ Eva Rohde, ${ }^{\text {II }}, \triangle \triangle$ Pia Siljander, $\boldsymbol{\Lambda} \mathbf{\Delta}, \nabla \nabla$ Guillaume van Niel, ${ }^{\perp \perp}$ M. Helena Vasconcelos, ${ }^{\text {II, }} \triangle, \nabla \nabla$ María Yáñez-Mó, $\triangleright$ Marjo L. Yliperttula, $\nabla \nabla$ Natasa Zarovni, Apolonija Bedina Zavec, $\square$ and Bernd Giebel*,

${ }^{\dagger}$ Anti-Tumor Drugs Section, Department of Therapeutic Research and Medicines Evaluation, National Institute of Health (ISS), 00161 Rome, Italy

${ }^{\ddagger}$ School of Pharmacy and Pharmaceutical Sciences \& Trinity Biomedical Sciences Institute, Trinity College Dublin, Dublin 2, Ireland

${ }^{\S}$ IVECAT-Group, Germans Trias i Pujol Research Institute (IGTP), and Nephrology Service, Germans Trias i Pujol University Hospital, Campus Can Ruti, 08916 Badalona, Spain

"Department of Genetics, Cell- and Immunobiology, Semmelweis University, 1085 Budapest, Hungary

${ }^{\perp}$ Molecular Biotechnology Center, Department of Medical Sciences, University of Turin, 8 Turin, Italy

${ }^{\#}$ Human Anatomy Section, Department of Experimental Biomedicine and Clinical Neuroscience, University of Palermo, and Euro-Mediterranean Institute of Science and Technology, 90133 Palermo, Italy

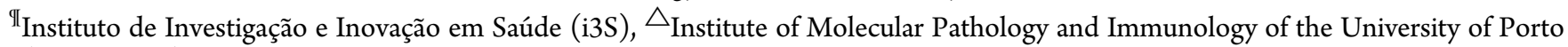
(IPATIMUP), 4200-135, Porto, Portugal

${ }^{\dagger \dagger}$ Department of Pathology and Oncology, Faculty of Medicine, University of Porto, 4200-319 Porto, Portugal

$\nabla$ Department of Biological Sciences, Faculty of Pharmacy, University of Porto, 4050-313 Porto, Portugal

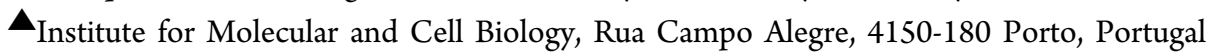

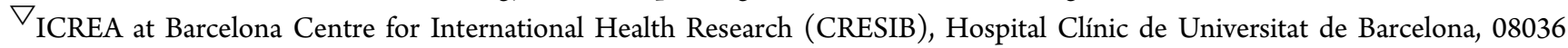
Barcelona, Spain

ICREA at Institut d'Investigació Germans Trias i Pujol (IGTP), 08916 Badalona, Spain

${ }^{\circ}$ Department of Laboratory Medicine, Karolinska Institutet, 17177 Stockholm, Sweden

- Department of Physiology, Anatomy and Genetics, University of Oxford, Oxford OX13QX, United Kingdom

$\square$ Sandoz Biopharmaceuticals-Lek Pharmaceuticals d.d., Mengeš, Slovenia

Institute of Experimental Neurology, Division of Neuroscience, San Raffaele Scientific Institute, 20132 Milan, Italy

OLaboratory of Experimental Cancer Research, Department of Radiation Oncology and Experimental Cancer Research, Ghent University Hospital, 9000 Gent, Belgium

- Science Faculty, Molecular Biology and Genetics Department, THORLAB- Therapeutic Oligonucleotide Research Lab, Bilkent University, 06800 Bilkent, Turkey

Laboratory of Clinical Biophysics, Faculty of Health Sciences, University of Ljubljana, 1000 Ljubljana, Slovenia

${ }^{\nabla}$ UMR-1280, INRA, and University of Nantes, 44300 Nantes, France

${ }^{\varnothing}$ Department of Immunochemistry and Glycobiology, Institute for the Application of Nuclear Energy, INEP, Univeristy of Belgrade, 11000 Belgrade, Serbia

${ }^{\$}$ Chemistry Department, University of Ioannina, 45110 Ioannina, Greece

${ }^{\&}$ University of Applied Sciences and Arts Northwestern Switzerland, Gründenstrasse 40, 4132 Muttenz, Switzerland 
$\iint$ Dpto. Biología Celular y Parasitologia, Facultat de Farmacia, and ${ }^{\otimes}$ Joint Research Unit on Endocrinology, Nutrition and Clinical Dietetics, Health Research Institute La Fe, Universitat de Valencia, 46010 València, Spain

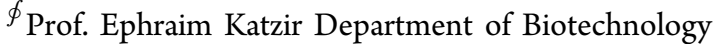

Engineering, ORT Braude College, Karmiel 2161002, Israel

${ }^{\infty}$ Dept. of Molecular Cell Biology, Institute for Cancer Research, Oslo University Hospital-The Norwegian Radium Hospital, 0379 Oslo, Norway

${ }^{\circledR}$ Institute for Environmental Health Sciences and Hospital Infection Control, Medical Center University of Freiburg, 79106 Freiburg am Breisgau, Germany

${ }^{\$}$ Mass Spectrometry and Proteomics, Institute of Biosciences and BioResources, National Research Council of Italy, 80131 Naples, Italy

${ }^{\S}$ Systems and Cell Biology of Neurodegeneration, University of Zurich, 8006 Zurich, Switzerland

${ }^{\perp \perp}$ Institut Curie, PSL Research University, UMR144, Centre de Recherche, 26 rue d'ULM, and Centre National de la Recherche Scientifique, UMR144, 75231 Paris, France

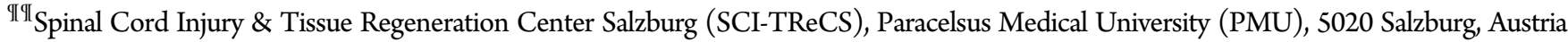

$\triangle \triangle$ Department of Blood Group Serology and Transfusion Medicine, University Hospital, Salzburger Landeskliniken GesmbH (SALK), 5020 Salzburg, Austria

$\Delta \boldsymbol{\Delta}_{\text {Division of Biochemistry and Biotechnology, Department of Biosciences, and }} \nabla \nabla$ Division of Pharmaceutical Biosciences, Faculty of Pharmacy, University of Helsinki, 00100 Helsinki, Finland

Unidad de Investigación, Hospital Sta Cristina, IIS-IP, Departamento Biología Molecular/CBM-SO, UAM, 28009 Madrid, Spain

Exosomics Siena SpA, 53100 Siena, Italy

$\square \square$ Laboratory for Molecular Biology and Nanobiotechnology, National Institute of Chemistry, 1000 Ljubljana, Slovenia

Institute for Transfusion Medicine, University Hospital Essen, University Duisburg-Essen, 45147 Essen, Germany

ABSTRACT: Recent research has demonstrated that all body fluids assessed contain substantial amounts of vesicles that range in size from 30 to $1000 \mathrm{~nm}$ and that are surrounded by phospholipid membranes containing different membrane microdomains such as lipid rafts and caveolae. The most prominent representatives of these so-called extracellular vesicles (EVs) are nanosized exosomes $(70-150 \mathrm{~nm})$, which are derivatives of the endosomal system, and microvesicles (100-1000 nm), which are produced by outward budding of the plasma membrane.

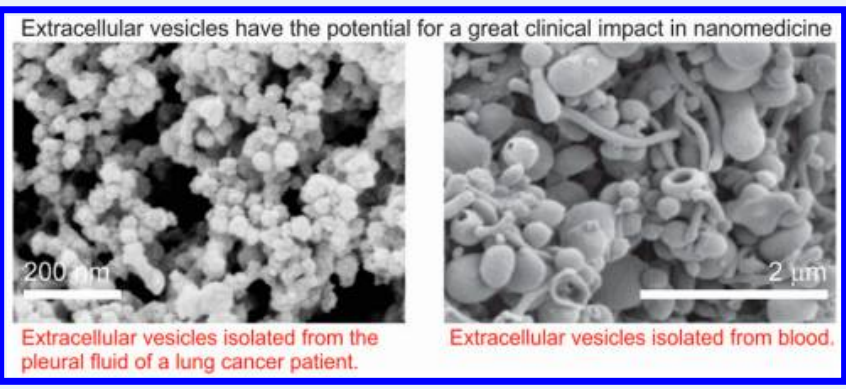
Nanosized EVs are released by almost all cell types and mediate targeted intercellular communication under physiological and pathophysiological conditions. Containing cell-typespecific signatures, EVs have been proposed as biomarkers in a variety of diseases. Furthermore, according to their physical functions, EVs of selected cell types have been used as therapeutic agents in immune therapy, vaccination trials, regenerative medicine, and drug delivery. Undoubtedly, the rapidly emerging field of basic and applied EV research will significantly influence the biomedicinal landscape in the future. In this Perspective, we, a network of European scientists from clinical, academic, and industry settings collaborating through the H2020 European Cooperation in Science and Technology (COST) program European Network on Microvesicles and Exosomes in Health and Disease (ME-HAD), demonstrate the high potential of nanosized EVs for both diagnostic and therapeutic (i.e., theranostic) areas of nanomedicine.

S trategic platforms for nanomedicine seek to exploit the improved (and often novel) physical, chemical, and biological properties of nanomaterials. However, these documents specify that there is an urgent need for biomimetism, namely, the process of simulating what occurs in nature. ${ }^{1-3}$

Extracellular vesicles (EVs), such as exosomes and small microvesicles, are nanovesicles, naturally released from cells in both normal or diseased states. Reflecting their cells of origin, these EVs are assembled by specific sets of molecules including proteins, lipids, metabolites, and nucleic acids. According to their molecular signature, they are able to interact specifically with selected target cells at local or distant sites, within or between organs. ${ }^{4}$ Considered to be a vectorized signaling system, they seem to bind to specific membrane microdomains on their target cells; among others, these membrane microdomains contain transmembrane receptors, integrins, and cell-adhesion molecules. To transmit their information, they either fuse with the plasma membrane or get incorporated by endocytotic processes (Figure 1). Thus, in addition to direct cell-cell contact and soluble factors (e.g., cytokines, chemokines, and hormones), EV-mediated signaling provides a third complex and targeted mode of intercellular communication. ${ }^{5}$ According to their features, EVs are ideal candidates to serve as biomarkers, nanosized drug-delivery vehicles, and mediators for a variety of therapeutics in oncology, immune therapy, and regenerative medicine. ${ }^{4,6}$ Thus, EVs have the potential for great clinical impact in nanomedicine. The dual potential of EVs as diagnostic tools and as therapeutic agents supports their use in "theranostics". This area of nanomedicine focuses on multidisciplinary research to set up new systems for various 


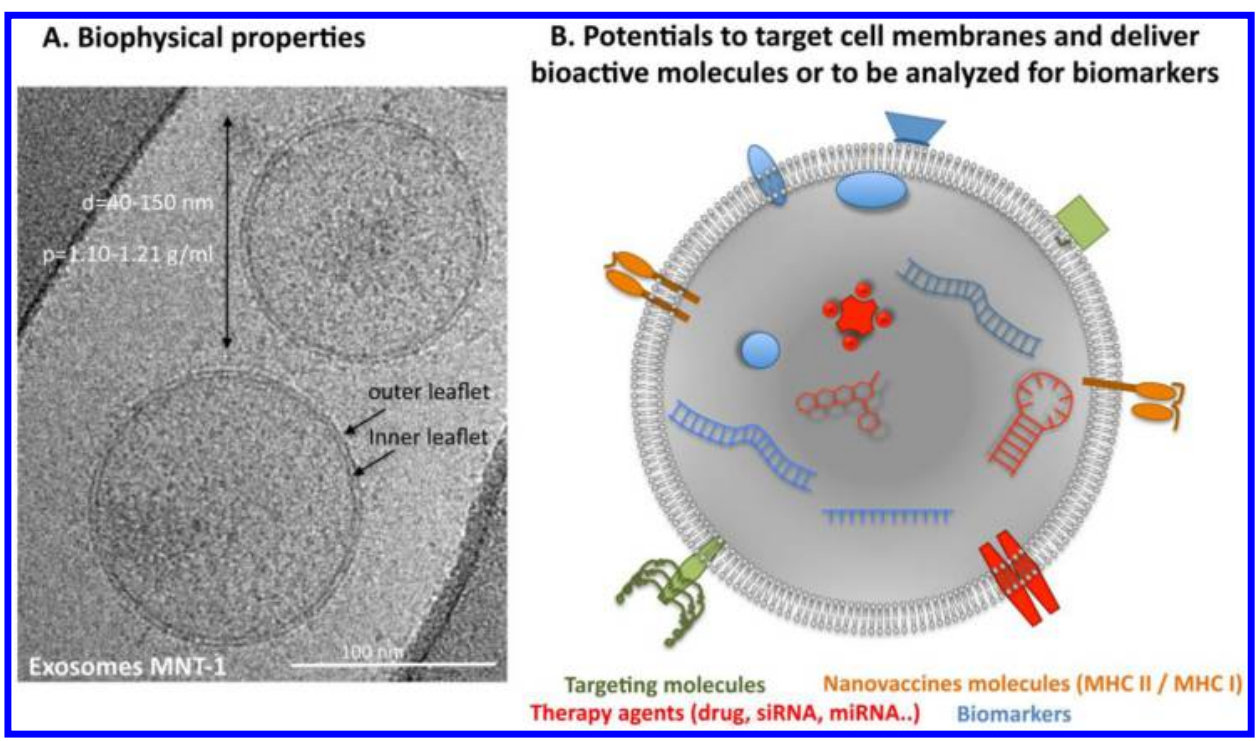

Figure 1. Exosomes, a natural source of nanoparticles to target cell membranes and deliver bioactive molecules or to be analyzed for biomarkers. (A) Extracellular vesicles are 50-300 $\mathrm{nm}$ vesicles surrounded by a lipid bilayer. Such physical characteristics are uniquely observed by cryo-electron microscopy (exemplified by a picture of exosomes derived from a human melanocytic cell line observed by cryo-EM. Credit: G. van Niel and A. Di Cicco. (B) Schematic representation of extracellular vesicles and the potential bioactive molecules and biomarkers that can be associated. Families of molecules of interest are classified by color codes as detailed in the text beneath. Credit: G. van Niel.

nanobiomedical applications, ranging from the medical use of nanoplatform-based diagnostic agents, to therapeutic agents, to possible future applications of diagnosis and therapy. ${ }^{7}$ Theranostics includes the early detection of diseases, the monitoring of therapeutic responses, and the targeted delivery of therapeutic agents. Theranostics at the nanoscale encompasses nanoprobes, nanocarriers, and nanodiagnostics. However, the most important task of a theranostic strategy concerns theranostic nanoformulations, which deal with the development of new agents based on a "whole-in-one approach", which should have maximal application in the field of personalized medicine. Extracellular vesicles appear to be ideal nanovectors for theranostics, with maximal potential for targeting the disease site with only minimal side effects. If successful, the proof-of-concept in the use of EVs as autologous or allogeneic nanovectors for both diagnosis and therapy of major diseases will enable widespread preclinical and clinical applications.

\section{NANOSIZED EXTRACELLULAR VESICLES AS DISEASE BIOMARKERS}

In this section, we present data supporting the future of nanosized EVs as potentially the most reliable biomarkers in medicine. The majority of the available clinical data have been obtained from studies of cancer patients. However, based on the more limited data emerging from studies of other pathologies, the ensemble of the data supports EVs found in bodily fluids as a source of biomarkers for all human diseases evaluated thus far. The current "equipment" of disease biomarkers represents an unmet clinical need, and so far, many approaches have searched for single molecules as biomarkers. As an example, prostate-specific antigen (PSA) is a prominent molecule that is used as a prostate cancer (PCa) marker. Plasma PSA determination is now used worldwide in PCa screening, and it rapidly replaced digital rectal examination for early detection of cancer. ${ }^{8,9}$ Plasma PSA is controversial as a PCa biomarker, however, ${ }^{10-12}$ due to the likelihood of false positives, including benign prostatic hyperplasia $(\mathrm{BPH}) .{ }^{11}$ Since PSA testing fails to discriminate between $\mathrm{BPH}$ and tumors, the use of this analysis causes overdiagnosis and overtreatment with consequent patients suffering side effects. ${ }^{11,13-15}$ Prostate-specific antigen values above $4.0 \mathrm{ng}$ per milliliter are considered abnormal; however, cutoff levels can change with age, race, and individual physiological condition, ${ }^{11,13,14}$ with no significant progress in the last decades. ${ }^{16}$ As multimolecular aggregates, EVs offer the unique opportunity to use a combination of different markers

\section{EVs have the potential for great clinical impact in nanomedicine.}

specifically expressed on tumor-derived EVs. In fact, serum PSA has been detected on plasma and urine- derived EVs in a large clinical study. ${ }^{17,18}$

Tumors. Tumor-derived EVs are proposed to contain a tumor-specific molecular signature, qualifying them as potential biomarkers in tumor diagnostics. ${ }^{19}$ Such EVs can be harvested from biofluids such as blood and, for some cancer types, urine. In addition to PSA, clinical studies on other EV-associated cancer biomarkers have already been described and are summarized in Table 1. For example, a retrospective study on EV-associated biomarkers in stages III and IV melanoma patients showed increased levels of plasmatic caveolin-1 and CD63-positive EVs. ${ }^{20}$ Researchers found that EV-associated caveolin-1 displayed a sensitivity of $69 \%$ and specificity of $96.3 \%$, whereas a conventional cancer biomarker used in the follow up of melanoma patients, such as lactate dehydrogenase $(\mathrm{LDH})$ serum levels, was altered in only $12.5 \%$ of patients. ${ }^{20}$ More recently, a study in patients with pancreatic cancer found that glypican-1 (GPC1)-positive EVs were detectable in the serum of patients with pancreatic cancer with high levels of specificity and sensitivity and could distinguish healthy subjects and patients with a benign pancreatic disease from patients with early- and late-stage pancreatic cancer. ${ }^{21}$ Moreover, breast cancer patients also presented high levels of GPC1 on EVs, suggesting that an increase of certain EV subtypes might represent a hallmark 
Table 1. Clinical Data Showing the Role of Nanosized Extracellular Vesicles as Tumor Biomarkers

\begin{tabular}{|c|c|c|c|c|c|}
\hline cancer biomarker & & indication & biofluid & clinical study size & ref \\
\hline PSA & prostate cancer & $\begin{array}{l}\text { screening/early } \\
\text { diagnosis }\end{array}$ & urine & controls $N=10$; disease $N=24$ & 17 \\
\hline PSA & prostate cancer & $\begin{array}{l}\text { screening/early } \\
\text { diagnosis }\end{array}$ & plasma & control $N=2$; disease $N=5$ & 18 \\
\hline EGFRvIII & glioblastoma & early diagnosis & serum & disease $N=30$ & 137 \\
\hline (phospho)Met & melanoma & $\begin{array}{l}\text { early diagnosis/ } \\
\text { prognosis }\end{array}$ & plasma & $\begin{array}{l}\text { Controls } N=7 \text {; stage III } N=24 \text {; stage IV } \\
\quad N=14\end{array}$ & 23 \\
\hline caveolin-1 & melanoma & early diagnosis & plasma & controls $N=58 ;$ disease $N=90$ & 20 \\
\hline survivin & prostate cancer & early diagnosis & olasma & $\mathrm{HD} N=8 ; \mathrm{BPH} N=20 ;$ disease $N=39$ & 25 \\
\hline $\mathrm{CD} 24$ & breast cancer & early diagnosis & serum & HD $N=14$, disease $N=18$ & 138 \\
\hline EGRF & lung cancer & $\begin{array}{l}\text { diagnosis/ } \\
\text { personalized } \\
\text { medicine }\end{array}$ & serum & HD $N=9 ;$ disease $N=9$ & 139 \\
\hline $\begin{array}{l}\text { miR-21, miR-141, miR-200a, miR-200b, } \\
\text { miR-200c, miR-203, miR-205, miR-214 }\end{array}$ & ovarian cancer & $\begin{array}{l}\text { early diagnosis/ } \\
\text { prognosis }\end{array}$ & serum & $\begin{array}{l}\text { HD } N=10 \text {; stage I } N=10 \text {; stage II } N=10 \text {; } \\
\text { stage III } N=20 \text {; stage IV } N=10\end{array}$ & 140 \\
\hline RNU6-1, miR-320, and miR-574-3p & glioblastoma & early diagnosis & serum & controls $N=50 ;$ disease $N=50$ & 141 \\
\hline TMPRSS2:ERG2 and PCA3 mRNAs & prostate cancer & early diagnosis & urine & blinded prospective study $N=30$ & 142 \\
\hline $\begin{array}{l}\text { let-7a, miR-1229, miR-1246, miR-150, } \\
\text { miR-21, miR-223, and miR-23a }\end{array}$ & colorectal cancer & early diagnosis & serum & controls $N=22$; disease $N=88$ & 142 \\
\hline miR-21, miR1225-5p & gastric cancer & prognosis & $\begin{array}{l}\text { peritoneal } \\
\text { lavage fluid }\end{array}$ & disease $N=24$ & 28 \\
\hline methylated LINE1 and SOX17 DNA & gastric cancer & diagnosis & gastric juice & HD $N=10 ;$ disease $N=20$ & 143 \\
\hline CCR6 and HER-2/neu & gastric cancer & prognosis & plasma & HD $N=10 ;$ disease $N=37$ & 144 \\
\hline $\begin{array}{l}\text { miR-151a-5p, miR-30a-3p, miR-200b-5p, } \\
\text { miR-629, miR-100, and miR-154-3p }\end{array}$ & lung cancer & early diagnosis & plasma & $\begin{array}{l}\mathrm{HD} N=10 \text {; benign disease } N=10 \\
\text { malignant disease } N=10\end{array}$ & 145 \\
\hline TGFB1 and MAGE3/6 & ovarian cancer & $\begin{array}{l}\text { prognosis/therapy } \\
\text { monitoring }\end{array}$ & plasma & $\begin{array}{l}\mathrm{HD} N=10 ; \text { benign disease } N=10 \text {; } \\
\text { malignant disease } N=22\end{array}$ & 146 \\
\hline TYRP2, HSP70, HSC70, VLA-4 & melanoma & prognosis & plasma & $\begin{array}{l}\text { HD } N=9 ; \text { stage I } N=2 ; \text { stage III } N=7 \\
\text { stage IV } N=18\end{array}$ & 23 \\
\hline $\operatorname{miR}-21$ & $\begin{array}{l}\text { human esophageal } \\
\text { cell carcinoma }\end{array}$ & prognosis & serum & HD $N=41 ;$ disease $N=51$ & 147 \\
\hline KRAS & pancreatic cancer & $\begin{array}{l}\text { personalized } \\
\text { medicine }\end{array}$ & serum & HD $N=2 ;$ disease $N=2$ & 148 \\
\hline BRAFV600E, EGFR & $\begin{array}{l}\text { lung cancer, } \\
\text { melanoma }\end{array}$ & $\begin{array}{l}\text { personalized } \\
\text { medicine }\end{array}$ & plasma & in vivo model $N=8$ & 96 \\
\hline Glypican-1 & pancreatic cancer & early diagnosis & serum & HD $N=100 ;$ disease $N=190$ & 21 \\
\hline Glypican-1 & breast cancer & early diagnosis & serum & HD $N=100 ;$ disease $N=32$ & 21 \\
\hline Hsp60 & colon cancer & $\begin{array}{l}\text { early diagnosis/ } \\
\text { follow up }\end{array}$ & plasma & controls $N=40 ;$ disease $N=57$ & Cappello \\
\hline MMP-9, DKP4, EMMPRIN, PODXL & $\begin{array}{l}\text { renal cell } \\
\text { carcinoma }\end{array}$ & $\begin{array}{l}\text { biomarker } \\
\text { discovery }\end{array}$ & urine & controls $N=23 ;$ RCC $N=29$ & 149 \\
\hline EDIL-3/Del1 & bladder cancer & $\begin{array}{l}\text { diagnostic/ } \\
\text { prognostic? }\end{array}$ & urine & controls $N=12$; patients $N=12$ & 150 \\
\hline $\begin{array}{l}\text { Presence: LASS2, GALNT1 } \\
\text { Absence: ARHGEF39 and FOXO3 }\end{array}$ & bladder cancer & diagnosis & urine & controls $N=11 ;$ patients $N=8$ & 151 \\
\hline TACSTD2 & bladder cancer & diagnosis & urine & controls $N=29 ;$ patients $N=37$ & 152 \\
\hline ITGA3 and ITGB1 & $\begin{array}{l}\text { metastatic prostate } \\
\text { cancer }\end{array}$ & detection & urine & $\begin{array}{l}\text { patients with } \mathrm{BPH}(N=5), \mathrm{PCa}(N=5) \text {, } \\
\text { and metastatic } \mathrm{PCa}(N=3)\end{array}$ & 153 \\
\hline$m i R-34 a$ & prostate cancer & $\begin{array}{l}\text { response to } \\
\text { treatment }\end{array}$ & urine & $\begin{array}{l}\text { controls } N=36 \text {; patients } N>100 \text { (different } \\
\text { disease stage) }\end{array}$ & 154 \\
\hline TM256, ADIRF, LAMTOR1 and others. & prostate cancer & $\begin{array}{l}\text { diagnosis/follow } \\
\text { up }\end{array}$ & urine & controls $N=15 ;$ prostate cancer $N=16$ & 155 \\
\hline AGR2 splice variants & prostate cancer & $\begin{array}{l}\text { screening/early } \\
\text { diagnosis }\end{array}$ & urine & BPH $N=15 ;$ prostate cancer $N=24$ & 156 \\
\hline
\end{tabular}

of malignant cancers in general. In fact, EV concentration could also be used as an indicator of clinical status. For example, when the effect of treatment with imatinib due to a gastrointestinal stromal tumor was monitored, researchers found that the concentration of EVs before the treatment was increased with respect to the control. ${ }^{22}$ Elevated levels of EV-expressing TYRP-2, VLA- 4, HSP70, and HSP90 have been detected in the plasma of melanoma patients. ${ }^{23}$ Both HSP70 and HSP90 belong to the family of heat shock proteins (HSPs), which may emerge as a novel class of EV-associated cancer biomarkers. ${ }^{19}$ Remarkably, EV-associated levels of HSP60 were dramatically decreased in colon cancer patients after surgical removal of the tumor. ${ }^{24}$ As previously mentioned, EVs may also shuttle wellknown tumor markers such as PSA. The EV-associated biomarker survivin has also been identified as a promising surrogate biomarker for early diagnosis of $\mathrm{PCa} .{ }^{25}$ Furthermore, in PCa patients, the EV concentration, as measured by nanoparticle tracking analysis (NTA), is higher than that in the plasma of healthy controls. ${ }^{26}$ Interesting results were obtained by comparing $\mathrm{N}$-glycan profiles of EVs from indolent and aggressive prostate cancer to those from noncancerous profiles. ${ }^{27}$ Other series of clinical data of paramount importance are summarized in Table 1. 
Interestingly, in addition to plasma and serum biofluids, other biofluids may represent valuable sources of EV biomarkers. Peritoneal lavage and gastric juice, for example, may represent promising, noninvasive, and informative sources for gastric cancer diagnosis and/or follow up. ${ }^{28}$

Bronchoalveolar lavage (BALF) is an excellent bioresource for studying lung disorders, including cancer. Bronchoalveolar lavage contains EVs with the morphology, density range, and cargo with different size and vesicular forms compared to that of lung surfactant aggregates. In humans, EVs recovered from BALF of healthy individuals were shown to contain major histocompatibility complex (MHC) molecules that may regulate the local immune defense. ${ }^{29}$ In sarcoidosis, however, the quantity of EVs is increased and they present a relatively greater quantity of MHC class I and class II molecules, as well as other bioactive molecules, such as neuregulin-1. Furthermore, they can activate autologous cells to produce inflammatory cytokines. ${ }^{30}$ In asthma, BALF EVs exhibit particular microRNA (miRNA) profiles $^{31}$ and carry the biosynthetic machinery for leukotriene biosynthesis. Different miRNA contents were found in BALF from non-small-cell lung cancer compared to that from plasma. ${ }^{32}$

Extracellular vesicles have also been isolated from nasal lavage fluid and can be used for studying upper airway diseases. ${ }^{33}$ Urinary EVs have also gained much attention as a source of biomarkers, as urine can be collected noninvasively in large amounts, and the isolated EVs are as stable as those from other biofluids. Urine contains highly heterogeneous populations of EVs that are released by the epithelial cells of the genitourinary system, ${ }^{34,35}$ and the molecular profiles of urinary EVs seem to directly reflect the pathophysiological state of this system. Therefore, EV-based diagnosis could represent an alternative to current diagnostics, which, for many diseases of the genitourinary system (kidney, bladder, prostate), rely on poorly predictive, relatively inaccurate biomarkers and/or on biopsy, which is associated with patient morbidity. Recently described isolation, purification, ${ }^{36}$ and analytical strategies for urinary EVs facilitate their in-depth molecular characterization in research settings $^{37,38}$ and also in hospital settings. ${ }^{39}$ During pathogenesis, the released EVs are subjected to disease-specific alterations that can be detected by in-depth proteomic, transcriptomic miRNA analyses or by metabolomics studies ${ }^{35}$ to reveal the disease-specific markers that may be validated in preclinical and clinical diagnostic platforms. Notably, studies of the molecular composition of urinary EVs have not been restricted to cancer. Extracellular vesicles may also provide a reliable source of molecules to help understand the metabolic and physiologic state of the urinary tract, providing suitable biomarkers for diseases such as kidney injury, glomerulonephritis, lupus nephritis, diabetic nephropathy, thin basement membrane nephropathy, polycystic kidney disease, and/or fibrosis. ${ }^{35}$

Neurodegenerative Diseases. Extracellular vesicles have been implicated in various neurodegenerative diseases including Alzheimer's disease (AD), Parkinson's, and amyotrophic lateral sclerosis. Central nervous system resident neural and non-neural cells all release EVs that can be detected in biological fluids, thus constituting a potentially beneficial source of information. In recent years, several groups have investigated EVs in blood and cerebrospinal fluid (CSF) during neurological diseases. ${ }^{40}$ In several cases, EV analysis is progressing to the clinic despite numerous technological limitations. Among stroke victims, several studies have reported that endothelium and platelets under stress conditions release EVs, whose increase in plasma is proportional to ischemic brain volume. ${ }^{41}$ In neurodegenerative disorders, the release of neurotoxic protein aggregates in association with EVs has been reported, ${ }^{42}$ and further investigations have explored the roles of EVs in the pathogenesis of these diseases. ${ }^{43}$ In fact, an interesting feature of neurodegenerative diseases is that they are characterized by the deposition of certain misfolded proteins into amyloid/amyloidlike aggregates in distinct regions of the brains. The misfolded versions of the proteins are suggested to be the primary culprits in the pathogenesis of $\mathrm{AD}$, for instance. Amyloid proteins are, in fact, released in association with EVs, fully in agreement with the intracellular pathways of amyloid-associated proteins. Both immunoelectron microscopy and density gradient separation of EVs demonstrate that they contain $\mathrm{A} \beta$ peptides, suggesting that cells released some of the $\mathrm{A} \beta$ peptides in association with EVs, which can enable further deposition of peptides into amyloid plaques or even facilitate long-range transport. Evidence that EVs can participate in the formation of amyloid plaques came from the observation that EVs contain many pro-amyloidogenic lipids such as cholesterol, gangliosides, and sphingolipids, further supporting the hypothesis that they may participate in amyloid formation. While many of the underlying studies indicate detrimental roles of EVs in promoting amyloids, there is some controversy in this regard, as EVs have also been proposed to have a protective role by aiding in the clearance of amyloids. 44,45 Extracellular vesicles detected in the CSF are also suggested to be a potential source of biomarkers for patients with dementia. ${ }^{46}$ Similarly, in patients affected by neuroinflammatory diseases such as multiple sclerosis, CSF EVs have been proposed as biomarkers for microglia activation, with the possibility of revealing the activation type (i.e., protective or detrimental), along with disease progression. ${ }^{47}$ Finally, seminal work has shown that glioblastoma EVs can be detected in plasma and reflect the corresponding brain tumor volume and its response to treatment, which is an extraordinary potential advancement over invasive brain biopsies or repeated imaging of the brain. ${ }^{48}$ These studies suggest that further investigations into the use of EVs as biomarkers are highly warranted for a series of neurological diseases.

Infectious Diseases. The definition of the role of EVs in the context of infection is still developing, as viruses, bacteria, fungi, protozoa, and helminths all secrete forms of EVs, and even prions have been detected in EVs. ${ }^{49,50}$ Clinically important pathogens like HIV-1 and hepatitis C and A viruses use EVs either to alter the host cell or to transport themselves to host cells. Infected cells can, in turn, release EVs that contain pathogen-associated molecular patterns (PAMPs) to stimulate the immune response. ${ }^{51}$ On the contrary, infectious agents can use EVs to spread infection, facilitating movement of infectious materials, and to evade the host immune system response. ${ }^{52}$ The Leishmania infantum parasite cultivation strategy used to accumulate exogenous antigens dramatically influences the composition of the recovered exoproteome, where an enrichment of proteins that are known to be essential for infection, such as GP63 or EF1, was observed. ${ }^{53}$ The first in vivo demonstration of EV secretion by a pathogen was reported in sand flies infected with Leishmania major. ${ }^{54}$ In this study, parasite EVs were coegested with the parasite during the insect's bite, influencing the host's infectious process and exacerbating the disease symptoms. Thus, EVs have been proposed as relevant candidates to add to the repertoire of virulence factors associated with vector-transmitted infections. ${ }^{54}$ Thus, there is great potential for EVs as future biomarkers for infectious diseases of different etiologies, including viral, bacterial, and parasitic diseases. ${ }^{4}$ 
Extracellular vesicles have been implicated in various neurodegenerative diseases including Alzheimer's disease, Parkinson's, and amyotrophic lateral sclerosis.

Autoimmune and Other Diseases. Extracellular vesicles seem to play key roles in autoimmune diseases. Behcet's disease (BD) is a complex multiorgan chronic inflammatory condition of unknown etiology wherein the genetic background and environmental factors are thought to be important contributors to disease pathogenesis. ${ }^{55}$ In $\mathrm{BD}$ patients, plasmapheresis has been shown to induce rapid short-term remission, suggesting that an unidentified plasma-associated factor could be a trigger of flare-ups. ${ }^{56}$ These patients were found to have elevated EV numbers in their plasma, and the majority of those EVs were derived from platelets. It has been proposed that a plasma EV number-based stratification of BD could more precisely identify inactive and active disease states and so could aid in its pharmacological management.

Glycosylation changes of EVs are being considered as disease biomarkers. In addition, other types of molecules, such as glycans, have been shown to be EV-linked biomarkers of different diseases, including some inflammatory and autoimmune diseases. For example, urinary EVs from patients with classical galactosemia are characterized by complex-type $\mathrm{N}$-linked glycosylation in contrast to healthy subjects whose EV glycosylation was mainly of high-mannose-type. ${ }^{57}$ Surface glycosylation of urinary EVs was also analyzed in autosomal dominant polycystic kidney disease (ADPKD). Here, lectin microarray analysis revealed that 6 out of 43 different lectins have different binding intensity to EVs from individuals with $\mathrm{ADPKD}$ compared to EVs from healthy subjects. ${ }^{58}$ All of these findings demonstrate the biomarker potential of EV glycans and the applicability of highthroughput techniques (such as lectin microarrays) in selecting lectins that can be used as the basis for establishing new diagnostic assays.

\section{NANOSIZED EXTRACELLULAR VESICLES AS THERAPEUTIC AGENTS}

Tumor and Infectious Disease Vaccination. As described above and previously reviewed, ${ }^{4}$ EVs from different cell types exert a variety of different physiological functions. Initiated with the observation that B-cell-derived EVs carry functional MHC-peptide complexes on their surface and contain the potential to exert $\mathrm{T}$ cell stimulatory functions, ${ }^{59}$ interest was raised in using EVs as immune modulatory agents. After it was shown that EVs derived from dendritic cells (DCs) pulsed with tumor antigens mediated antitumor responses, ${ }^{60}$ limited numbers of preclinical and clinical trials investigated the role of DC-derived EVs as antitumor therapies. So far, two phase I clinical trials have been performed, one in France and one in the United States, to treat melanoma or small-cell lung carcinoma patients, respectively (Table 2). ${ }^{61,62}$ The trials mainly demonstrated feasibility and safety; a small number of patients benefited from the treatment, resulting in the initiation of a clinical phase II trial in France to treat non-small-cell lung cancer patients. ${ }^{63}$ Although the later therapy did not induce detectable effector $\mathrm{T}$ cell responses, a positive effect on natural killer (NK) cells was observed in some patients. ${ }^{64}$ Following the same strategy, EVs from DCs pulsed with pathogens of infectious disease, such as fungi, bacteria, parasitic protozoa, and helminths, might be useful as agents in anti-infectious disease treatment. In fact, proof-of-principle trials have been performed with DC-EVs obtained from Toxoplasma gondii-pulsed DCs. Indeed, such EVs conferred protection against subsequent Toxoplasma infections in preclinical models. ${ }^{6-67}$ Proof-ofprinciple vaccination trials have been also performed in preclinical animal models for malaria infection. Here, application of EVs from infected reticulocytes were found to protect mice from lethal Plasmodium yoelii infections, ${ }^{68}$ thus reinforcing the use of EVs as a new therapeutic approach against parasitic diseases.

Table 2. Therapeutic Application of EVs in Human Clinical Trials and a Treatment Attempt

\begin{tabular}{|c|c|c|c|c|c|c|}
\hline EV source & disease & EV modification & phase & official clinical study title & study size & ref \\
\hline $\begin{array}{l}\text { dendritic cells pulsed with } \\
\text { antigenic peptides }\end{array}$ & melanoma & & phase I & & $n=15$ & 61 \\
\hline $\begin{array}{l}\text { dendritic cells pulsed with } \\
\text { antigenic peptides }\end{array}$ & $\begin{array}{l}\text { non-small lung } \\
\text { cancer }\end{array}$ & & phase I & & $n=13$ & 62 \\
\hline $\begin{array}{l}\text { dendritic cells pulsed with } \\
\text { antigenic peptides }\end{array}$ & $\begin{array}{l}\text { non-small-cell } \\
\text { lung cancer }\end{array}$ & & phase II & $\begin{array}{l}\text { phase II trial of a vaccination with tumor } \\
\text { antigen-loaded dendritic cell-derived } \\
\text { exosomes on patients with unresectable } \\
\text { non-small-cell lung cancer responding to } \\
\text { induction chemotherapy }\end{array}$ & $n=22$ & NCT01159288 64 \\
\hline ascites & $\begin{array}{l}\text { colorectal } \\
\text { cancer }\end{array}$ & & phase I & & $n=40$ & 74 \\
\hline MSCs & type I diabetes & & phase I & $\begin{array}{l}\text { phase I study of the effect of cell-free cord blood } \\
\text { derived microvesicles on } \beta \text {-cell mass in type } 1 \\
\text { diabetes mellitus (T1DM) patients }\end{array}$ & $n=20$ & NCT02138331 \\
\hline MSCs & GvHD & & $\begin{array}{r}\text { treatment } \\
\text { attempt }\end{array}$ & & $n=1$ & 76 \\
\hline plant nanovesicles & colon cancer & curcumin loaded & phase I & $\begin{array}{l}\text { phase I clinical trial investigating the ability of } \\
\text { plant exosomes to deliver curcumin to normal } \\
\text { and malignant colon tissue }\end{array}$ & $n=35$ & NCT01294072 \\
\hline tumor cells & $\begin{array}{l}\text { malignant } \\
\text { pleural } \\
\text { effusion }\end{array}$ & $\begin{array}{l}\text { chemotherapeutic } \\
\text { drug loaded }\end{array}$ & phase II & $\begin{array}{l}\text { phase II study of tumor cell-derived } \\
\text { microparticles used as vectors of } \\
\text { chemotherapeutic drugs to treat malignant } \\
\text { ascites and pleural effusion }\end{array}$ & $n=22$ & NCT01854866 \\
\hline
\end{tabular}


In other settings, EVs directly released from pathogens or from pathogen-infected cells have been used to pulse DCs in vitro or for subsequent in vivo vaccination in a number of preclinical models. ${ }^{6,69}$ In a similar context, outer membrane vesicles (OMVs), which are continuously produced by Gramnegative bacteria by vesiculation of the outer membrane,$^{70}$ have successfully been used as vaccines. ${ }^{71}$ For example, an OMVbased vaccine named Bexsero has been generated by Novartis. It efficiently protects against Neisseria meningitides infections and is used as a vaccine against serogroup B meningococcal diseases in children. ${ }^{72,73}$ Extracellular vesicles as vaccines have also been used in antitumor therapy. Specifically, in a phase I clinical trial performed in China, EVs from ascites fluid from colorectal cancer patients were used as a vaccine to trigger antitumor activities of DCs (Table 2). Feasibility and safety were demonstrated. ${ }^{74}$ Preclinical and clinical EV-based vaccination trials for antitumor treatment or to fight infectious diseases indicate that this therapeutic concept is safe and feasible. The future will show how this can be translated as nanomedicinal approaches in clinics.

Immune Suppressive and Regenerative Therapies. Patient cohorts with a variety of different degenerative and inflammatory diseases have been treated with somatic stem cells, especially with mesenchymal stem cells (MSC), either to promote regeneration or to suppress inflammation. ${ }^{75}$ Contrary to the original assumption that stem cells integrate into affected tissue to exert their therapeutic function, they instead seem to act in a paracrine rather than in a cellular manner. The results of increasing numbers of studies in preclinical models and a single treatment attempt of a graft versus host disease patient suggest that EVs exert the stem cells' therapeutic effects. ${ }^{6,76-78}$ Head-to-head comparisons of MSC and MSC-EV applications have been performed in animal models for acute kidney failure $^{79}$ and ischemic stroke. ${ }^{80}$ Significant differences were undetected.

Thus, it is feasible that, in the future, stem-cell-derived EVs could be used instead of stem cells to treat various diseases. There are several challenges to be addressed before stem-cellderived EVs can be approved for the treatment of certain diseases, but compared to therapies with stem cells, they provide a variety of advantages. In contrast to cells as non-self-renewing units, EVs lack any endogenous tumor-formation potential. Furthermore, they can be sterilized by filtration through $0.22 \mu \mathrm{m}$ filters and can be handled, stored, and characterized more easily than cells. However, it has to be considered that any given EV samples may provide heterogeneous mixtures of different EV subentities, all containing different compositions. For biological activity, heterogeneity may be an important parameter, as EVs may concomitantly convey multiple signals that act synergistically for a defined activity. However, this heterogeneity provides a challenge to the standardization of EV preparations. Recent findings indicate that EVs released from stem/progenitor cells promote tissue regeneration by modulation of gene transcription and induction of epigenetic changes in recipient cells and by delivering growth factors, ${ }^{81}$ but studies on the mode of action and identification of potentially healing molecules carried by EVs are a challenge for the field. Rapid translation of EV products for therapeutic use is also challenged by the lack of standard purification and characterization methods that can be used in clinical settings. ${ }^{6}$ However, a number of research groups and companies are working on these challenges. It is highly likely that stem-cell-derived EVs as well as EVs from other cell types (e.g., endothelial cell or regulatory
$\mathrm{T}$ cells ${ }^{82-87}$ ) will advance to clinical applications within the next few years. Treatments of a range of diseases have been considered as potentially profiting from EV therapies, including autoimmune, chronic, and acute inflammatory diseases such as rheumatoid arthritis, inflammation of connective and vascular tissues, autoimmune inflammatory disease, intestinal chronic inflammatory diseases, Crohn's diseases and ulcerative colitis, type 1 diabetes, multiple sclerosis, cystic fibrosis, graft versus host disease, as well as diseases associated with acute tissue damage such as myocardial infarction, ischemic stroke, acute and chronic kidney failure, drug-induced liver injury, hypoxia-induced pulmonary hypertension, hind limb ischemia, and perinatal asphyxia.

Further, within the context of EV research, parasites (including helminths) have been shown to produce EVs expressing immunomodulatory molecules. ${ }^{50}$ Such EVs have been considered for the treatment of autoimmune disorders. ${ }^{88}$ Indeed, recent studies have shown the usefulness of EVs from Heligmosomoides polygyrus, a parasitic roundworm, in a rodent model of allergy.

Drug Delivery. From an applied perspective, synthetic lipoproteins have long been considered to be viable nanocarriers for targeted delivery of drugs ${ }^{90-93}$ because numerous cancers overexpress light density lipoprotein receptor. The most widely exploited drug-delivery platform is based on liposomes or lipid-based nanoparticles (LNPs). These nanoformulations have been used effectively to encapsulate various macromolecular drugs including proteins, chemotherapeutics, imaging agents, and different species of therapeutic RNAs (e.g., small interfering RNA, siRNA). Many of these bind to apolipoprotein E (ApoE) in blood and facilitate efficient delivery to the liver. ${ }^{92}$ Despite being effective, the main limitations with current nanocarriers based on LNPs are potential toxicity/immunogenecity and limited ability to penetrate organs and tissues outside the reticuloendothelial system (RES). Hence, EVs have emerged as candidates for drug delivery. Several reports have indicated the high delivery potential of EVs, such as paclitaxel in autologous prostate cancer EVs, ${ }^{93}$ in particular, in relation to endogenous protein and miRNA transfer. ${ }^{94}$ Furthermore, they can contain gDNA. ${ }^{95,96}$ Extracellular vesicles have also successfully been used to deliver exogenous drugs such as small molecules, miRNAs, and siRNAs. ${ }^{97}$ Recently, it was demonstrated that even an exogenous protein (catalase) can be loaded into EVs and subsequently confer neuroprotection in models of Parkinson's disease. ${ }^{98}$

By engineering EVs to display targeting moieties, tissues beyond the RES are amenable to targeting even after systemic delivery. ${ }^{99,100}$ Although EVs hold true potential as drug-delivery platforms, we note that the efficacy of loading of the lipophilic small drugs is good, ${ }^{94}$ but in the case of siRNA, it is very low. ${ }^{101}$ Similarly, in the case of endogenous miRNA transfer with EVs, caution has to be taken, as the majority of extracellular RNA is not associated with EVs. ${ }^{102}$ Thus, strategies are needed that can increase exogenous drug loading or methods of manipulating producer cells that permit selective loading of proteins or RNA into EVs. Examples where loading of drugs (in addition to the self-assembly of lipophilic drugs) could be achieved include the use of extruded vesicles from cells as well as synthetic EVs. ${ }^{103-105}$ However, it remains to be shown whether such systems are equally effective and safe as naturally secreted and purified EVs. In this context, it is interesting to note that exosomes released from melanocytes and melanoma cells were recently found to interact physically with ApoE-associated 
lipoparticles, maybe indicating that each of the different nanomessengers can be combined to make use of each of their advantages as a drug-delivery tool. ${ }^{106}$

Nanoparticle PEGylation (PEG is a coiled polymer of repeating ethylene ether units with dynamic conformations) is the current standard for stealth in nanoparticle drug delivery. However, potential immunological response and absence of active targeting prevent its widespread use. ${ }^{107}$ PEGylated nanoparticles rely on the enhanced permeability and retention (EPR) effect for tumor targeting, which is absent if primary tumors or metastases are smaller than $100 \mathrm{~mm}^{3} .{ }^{108}$ Bioconjugation approaches of PEGylated nanoparticles with targeting ligands to self-organize into some useful conformation are ambiguous because of denaturation of proteins during the conjugation process and the overall difficulty of duplicating biological complexity on the nanoscale. ${ }^{109}$ These disadvantages are largely absent when functionalizing PLGA (poly(lactic-co-glycolic acid)), gold, or silicon nanoparticles with cellular plasma membranes. This has already been successfully demonstrated with cancer cell membranes to induce an immune response (i.e., as a vaccination $)^{110}$ and by leukocyte and erythrocyte membranes to enhance circulation times (i.e., by avoiding immune uptake $)^{109,111}$ and increasing cancer cell specificity. ${ }^{111}$ These hybrids possess the ease-of-use and flexibility of synthetic materials, as well as the functionality and complexity of natural materials. Thus, EV-sized, cell-membrane-camouflaged nanoparticles are a delivery strategy with the potential to improve the therapeutic efficacy of the treatment of a variety of diseases.

Extracellular Vesicles in Milk. According to epidemiological analysis, human milk is better than artificial infant formula in allowing appropriate metabolic programming and protecting the baby against conditions such as type 2 diabetes, obesity, and hypertension in later life. Purification of EVs from breast milk has been described. ${ }^{112,113}$

\section{EV-sized, cell-membrane-camouflaged nanoparticles are a delivery strategy with the potential to improve the therapeutic efficacy of the treatment of a variety of diseases.}

Breast milk is rich in many bioactive molecules all sent to the baby in different packaging (e.g., exfoliated cells, microvesicles, fat globules). Finding and using natural sources of EVs loaded with bioactive miRNA from mammals will require extensive effort in purifying and characterizing EVs both from milk and from digestive fluids of the baby. The design of artificial nanoparticles for breast milk supplementation remains unresolved.

Other Therapeutic Implications. In discussing EVs' potential for therapy, a number of glycobiological aspects of EVs are worth mentioning. First, from a fundamental point of view, glycans (as other molecules) are specifically enriched or excluded from EVs. The fact that A/B blood group antigens are excluded from EVs compared to the plasma membrane is what enables EVs to be used therapeutically. ${ }^{114}$ Second, from a technological point of view, specific targeting of EVs loaded with therapeutics may be accomplished by displaying peptides on their surfaces. An associated issue is proteolytical degradation of such peptides in circulation, but this can be prevented by introducing a glycosylation motif at specific positions, without influencing protein-target interactions. ${ }^{115}$ Third, for applica- tions, specific glyco-profiles of EVs related to several diseases were detected by lectins, and new adjuvant cancer therapy strategies employing lectins to remove circulating cancer-derived EVs selectively have been proposed. ${ }^{116}$

Extracellular Vesicles in Cosmetics. Recent studies have highlighted roles for EVs in the skin. Maintenance of skin pigmentation, which is required for skin color and for photoprotection against harmful UV radiation, is the consequence of tight intercellular communication between keratinocytes and melanocytes. In an academic-industrial collaboration between the Raposo group and Clarins Laboratories, it was shown that human primary keratinocytes secrete EVs that are targeted to melanocytes to modulate pigmentation. Extracellular vesicles are key actors in skin pigmentation, enhancing melanin synthesis by increasing the expression and activity of melanosomal proteins. ${ }^{117}$ These effects are connected to particular miRNA compositions. Furthermore, the function of keratinocyte-derived EVs has been demonstrated to be photo-type-dependent and is modulated by UVB. This study not only uncovers an important physiological function for EVs in our understanding of how pigmentation is regulated by intercellular communication but also opens new avenues for technological development. For example, based on these findings, Clarins recently launched a new product that, likely by acting on the composition of EVs, inhibits overproduction of melanin ("Sérum Mission Perfection de Clarins").

\section{PRECLINICAL DATA SUPPORT A GREAT FUTURE FOR NANOSIZED EXTRACELLULAR VESICLES IN NANOMEDICINE}

Based on the clinical evidence (outlined above) showing that EVs may be exploited as either disease biomarkers or therapeutic tools, it is conceivable that EVs may represent key players in the future of nanomedicine and, in particular, in the field aimed at defining the most biomimetic approach in nanomedicine. The presence of EVs in the plasma of both healthy individuals and those with various diseases suggests that EVs may serve as vectors for transferring information to tissues and organs far from their places of production, that is, acting in a paracrine manner.

These actions indicate that EVs may well diffuse normal, abnormal, or aberrant messages to cells both close to their origins and at distances. This, in turn, suggests that EVs may play key roles as nanodevices belonging to integrated networks involved in multiple pathophysiologies. Our current understanding is that EVs are key regulators of normal functions of the body. ${ }^{4}$

It is conceivable that in the near future nanosized EVs may be helpful in the screening and diagnosis of viral diseases. In fact, we have evidence that EVs are natural delivery systems for a variety of viruses including EBV, HCV, HIV, coxsackie virus B1, and hepatitis A. ${ }^{18-124}$ Moreover, prion proteins are shuttled by nanovesicles, although only preclinical data are available to date. ${ }^{125-129}$ The data strongly suggest that EV-based tests will be included in new screening approaches for transmissible diseases, for example, in blood donors.

Preclinical data also support the use of EVs as the most biomimetic nanovectors for a variety of molecules, including proteins, nucleic acids, and chemicals. Nanosized EV-encapsulated curcumin, delivered by the intranasal route, is efficient in preventing brain inflammation and is more effective than curcumin alone. ${ }^{130}$ Moreover, EVs released by human tumor cells or human tumors treated with cisplatin contain cisplatin in its active/native form. ${ }^{131}$ The future of the clinical use of EVs 
depends on a high level of networking between researchers involved in the field and a strategic approach on how to guide future research. A level of consensus was recently achieved by the International Society for Extracellular Vesicles (ISEV), although it has not yet been fully implemented in clinical studies. ${ }^{6,132,133}$

Funded by Europe's Horizon 2020 program, a consortium of academic, clinical, and industry partners with a common interest in EVs has been established. This cooperation in science and technology, entitled the European Network on Microvesicles and Exosomes in Health and Disease (ME-HaD), includes EV researchers from 27 European countries and allied groups from the United States and Australia. The aim of ME-HaD is to foster multidisciplinary approaches to research in this field, including the theranostic relevance of EVs, with the ultimate goal of exploiting EVs for clinical applications, which is achievable only through coordinated efforts and valorization. Guided, mentored, and trained by more experienced EV researchers within $\mathrm{ME}-\mathrm{HaD}$, this consortium currently includes membership of more than 250 early stage researchers, who will hopefully be the future leaders in the field of EV research and application.

\section{THE FUTURE OF EXTRACELLULAR VESICLES IN NANOMEDICINE AND INDUSTRY INVESTMENT}

The life science market is remarkably conservative, relative to the extremely dynamic EV market. For instance, ultracentrifugation is still the gold standard for EV isolation, used by $\sim 60 \%$ of researchers in the field. The acceptance of novel commercial tools is slow. The pharma industry, however, is open to EV-based solutions in companion diagnostics and personalized medicine if they are reliable and specific for EVs. Thus, EV analysis will likely enable rapid in vitro diagnostic or laboratory-developed/exoteric tests for hospitals or centralized laboratories and will also be tools for quality control of production processes and surrogate markers for the development of novel therapies.

1. In order to surmount regulatory hurdles (which are diverse and rapidly evolving in the biggest markets, such as the United States, the European Union, and Asia) and both market and cultural insertion, extensive clinical validation and technology beta testing is needed. This calls for time, money, and collaborative research efforts including multiple stakeholders so as to produce definitive evidence that EV marker assays outperform and/or complement conventional diagnostics, thus leading to a broad acceptance from clinicians and patients.

2. The technological readiness level of EV analysis might not be sufficiently robust. Fabrication of novel materials and sophisticated devices (microfluidic chips or specific sensors) has produced some exciting proof-of-concept applications of advanced technologies. These have limited application in routine laboratory practice, however, due to cost or because they still are not guaranteed to work in "all hands", according to their inventors. On the other hand, we have convincing evidence of EV detection and analysis using cost-effective and familiar formats of assays that are compatible with off-the-shelf laboratory equipment such as plate readers or polymerase chain reaction (PCR) cyclers. ${ }^{20,134}$

Extensive developments in the field of EVs, in particular, the promising preliminary results from using EVs, therapeutically and as diagnostics markers, has resulted in a number of start-ups that have initiated commercialization of these achievements. Big and small pharmaceutical companies have already taken first steps in evaluating development, costs of the investments, and registration and commercialization strategies. Promising results and demands for new therapeutic EV development will, undoubtedly, stimulate pharmaceutical industry interest in the production of therapeutic EVs at larger scales.

The active participation of the pharmaceutical industry should support the development of the field of EVs. Large companies, with a high volume of starting material and the availability of analytical tools, will accelerate development of the detection and characterization of EVs by both the evaluation of commonly used techniques and the development of new techniques. In addition, the pharmaceutical industry's high demands for quality regulation will accelerate standardization of EV sample collection, isolation, and analysis methods, which are highly desirable outcomes.

\section{CONCLUSIONS AND PROSPECTS}

Nanosized EVs, which may both contain disease biomarkers and/or be the vectors of potential therapeutic molecules, thus represent the ideal theranostic approach. This new multidisciplinary field focuses on building nanosystems for future joint applications of diagnosis and therapy. The theranostic "all-in-one approach" has great potential in the field of personalized medicine, as it enables the detection and monitoring of a disease in individual patients, possibly in early clinical stages, as well as targeted drug delivery at the site of the disease. Here, we have included data dealing with clinical studies and provided evidence that EVs are currently used in clinical research as biomarkers of disease and as therapeutic tools. Thus, this Perspective emphasizes the evidence that natural nanosized EVs are critical to the future of nanomedicine.

\section{AUTHOR INFORMATION}

\section{Corresponding Authors}

*E-mail: stefano.fais@iss.it.

*E-mail: bernd.giebel@uk-essen.de.

\section{Notes}

Views expressed in this Perspective are those of the authors and not necessarily the views of the ACS.

The authors declare no competing financial interest.

\section{ACKNOWLEDGMENTS}

The authors acknowledge the european COST action for supporting the European Network on Microvesicles and Exosomes in Health and Disease (ME-HaD, BM1202, www. cost.eu/COST_Actions/BMBS/Actions/BM1202) who funded parts of the publication of this work. Pictures of the graphical abstract were adapted from Šuštar et al. ${ }^{135}$ and MrvarBrecko et al. ${ }^{136}$

\section{REFERENCES}

(1) ftp://ftp.cordis.europa.eu/pub/etp/docs/swd-2013-strategy-etp2020 en.pdf (Accessed December 21, 2015).

(2) http://www.etp-nanomedicine.eu/public/press-documents/ publications/etpn-publications/etpn-white-paper-H2020 (Accessed December 21, 2015).

(3) ftp://ftp.cordis.europa.eu/pub/nanotechnology/docs/ nanomedicine bat en.pdf (Accessed December 21, 2015).

(4) Yanez-Mo, M.; Siljander, P. R.; Andreu, Z.; Zavec, A. B.; Borras, F. E.; Buzas, E. I.; Buzas, K.; Casal, E.; Cappello, F.; Carvalho, J.; Colas, E.; Cordeiro-da Silva, A.; Fais, S.; Falcon-Perez, J. M.; Ghobrial, I. M.; Giebel, B.; Gimona, M.; Graner, M.; Gursel, I.; Gursel, M.; et al. Biological Properties of Extracellular Vesicles and their Physiological Functions. I. Extracell. Vesicles 2015, 4, 27066. 
(5) Ludwig, A. K.; Giebel, B. Exosomes: Small Vesicles Participating in Intercellular Communication. Int. J. Biochem. Cell Biol. 2012, 44, $11-15$.

(6) Lener, T.; Gimona, M.; Aigner, L.; Börger, V.; Buzas, E.; Camussi, G.; Chaput, N.; Chatterjee, D.; Court, F. A.; del Portillo, H. A.; O’Driscoll, L.; Fais, S.; Falcon-Perez, J. M.; Felderhoff-Mueser, U.; Fraile, L.; Gho, Y. S.; Görgens, A.; Gupta, R. C.; Hendrix, A.; Hermann, D. M.; et al. Applying Extracellular Vesicles Based Therapeutics in Clinical Trials - An ISEV Position Paper. J. Extracell. Vesicles 2015, 4, 30087.

(7) Lammers, T.; Aime, S.; Hennink, W. E.; Storm, G.; Kiessling, F. Theranostic Nanomedicine. Acc. Chem. Res. 2011, 44, 1029-1038.

(8) Catalona, W. J.; Smith, D. S.; Ratliff, T. L.; Dodds, K. M.; Coplen, D. E.; Yuan, J. J. J.; Petros, J. A.; Andriole, G. L. Measurement of Prostate-Specific Antigen in Serum as a Screening-Test for ProstateCancer. N. Engl. I. Med. 1991, 324, 1156-1161.

(9) Brawley, O. W. Trends in Prostate Cancer in the United States. J. Natl. Cancer Inst. Monogr. 2012, 2012, 152-156.

(10) Andriole, G. L.; Crawford, E. D.; Grubb, R. L., 3rd; Buys, S. S.; Chia, D.; Church, T. R.; Fouad, M. N.; Gelmann, E. P.; Kvale, P. A.; Reding, D. J.; Weissfeld, J. L.; Yokochi, L. A.; O’Brien, B.; Clapp, J. D.; Rathmell, J. M.; Riley, T. L.; Hayes, R. B.; Kramer, B. S.; Izmirlian, G.; Miller, A. B.; et al. Mortality Results from a Randomized ProstateCancer Screening Trial. N. Engl. J. Med. 2009, 360, 1310-1319.

(11) Hoffman, R. M. Clinical Practice. Screening for Prostate Cancer. N. Engl. I. Med. 2011, 365, 2013-2019.

(12) Sturgeon, C. M.; Duffy, M. J.; Stenman, U. H.; Lilja, H.; Brunner, N.; Chan, D. W.; Babaian, R.; Bast, R. C.; Dowell, B.; Esteva, F. J.; Haglund, C.; Harbeck, N.; Hayes, D. F.; Holten-Andersen, M.; Klee, G. G.; Lamerz, R.; Looijenga, L. H.; Molina, R.; Nielsen, H. J.; Rittenhouse, H.; et al. National Academy of Clinical Biochemistry Laboratory Medicine Practice Guidelines for Use of Tumor Markers in Testicular, Prostate, Colorectal, Breast, and Ovarian Cancers. Clin. Chem. 2008, 54, E11-E79.

(13) Schroder, F. H.; Hugosson, J.; Roobol, M. J.; Tammela, T. L.; Ciatto, S.; Nelen, V.; Kwiatkowski, M.; Lujan, M.; Lilja, H.; Zappa, M.; Denis, L. J.; Recker, F.; Berenguer, A.; Maattanen, L.; Bangma, C. H.; Aus, G.; Villers, A.; Rebillard, X.; van der Kwast, T.; Blijenberg, B. G.; et al. Screening and Prostate-Cancer Mortality in a Randomized European Studv. N. Engl. I. Med. 2009, 360, 1320-1328.

(14) Etzioni, R; Feuer, E. Studies of Prostate-Cancer Mortality: Caution Advised. Lancet Oncol. 2008, 9, 407-409.

(15) Vickers, A. J.; Sjoberg, D. D.; Ulmert, D.; Vertosick, E.; Roobol, M. J.; Thompson, I.; Heijnsdijk, E. A.; De Koning, H.; Atoria-Swartz, C.; Scardino, P. T.; Lilja, H. Empirical Estimates of Prostate Cancer Overdiagnosis by Age and Prostate-Specific Antigen. BMC Med. 2014, 12,26

(16) Steuber, T.; O’Brien, M. F.; Lilja, H. Serum Markers for Prostate Cancer: A Rational Approach to the Literature. Eur. Urol. 2008, 54, $31-40$.

(17) Mitchell, P. J.; Welton, J.; Staffurth, J.; Court, J.; Mason, M. D.; Tabi, Z.; Clayton, A. Can Urinary Exosomes Act as Treatment Response Markers in Prostate Cancer? I. Transl. Med. 2009, 7, 4.

(18) Mizutani, K.; Terazawa, R.; Kameyama, K.; Kato, T.; Horie, K.; Tsuchiya, T.; Seike, K.; Ehara, H.; Fujita, Y.; Kawakami, K.; Ito, M.; Deguchi, T. Isolation of Prostate Cancer-Related Exosomes. Anticancer Res. 2014, 34, 3419-3423.

(19) Zocco, D.; Ferruzzi, P.; Cappello, F.; Kuo, W. P.; Fais, S. Extracellular Vesicles as Shuttles of Tumor Biomarkers and AntiTumor Drugs. Front. Oncol. 2014, 4, 267.

(20) Logozzi, M.; De Milito, A.; Lugini, L.; Borghi, M.; Calabro, L.; Spada, M.; Perdicchio, M.; Marino, M. L.; Federici, C.; Iessi, E.; Brambilla, D.; Venturi, G.; Lozupone, F.; Santinami, M.; Huber, V.; Maio, M.; Rivoltini, L.; Fais, S. High Levels of Exosomes Expressing CD63 and Caveolin-1 in Plasma of Melanoma Patients. PLoS One 2009, 4, e5219.

(21) Melo, S. A.; Luecke, L. B.; Kahlert, C.; Fernandez, A. F.; Gammon, S. T.; Kaye, J.; LeBleu, V. S.; Mittendorf, E. A.; Weitz, J.; Rahbari, N.; Reissfelder, C.; Pilarsky, C.; Fraga, M. F.; Piwnica-Worms,
D.; Kalluri, R. Glypican-1 Identifies Cancer Exosomes and Detects Early Pancreatic Cancer. Nature 2015, 523, 177-82.

(22) Ogorevc, E.; Kralj-Iglic, V.; Veranic, P. The Role of Extracellular Vesicles in Phenotypic Cancer Transformation. Radiol. Oncol. 2013, 47, 197-205.

(23) Peinado, H.; Aleckovic, M.; Lavotshkin, S.; Matei, I.; CostaSilva, B.; Moreno-Bueno, G.; Hergueta-Redondo, M.; Williams, C.; Garcia-Santos, G.; Ghajar, C.; Nitadori-Hoshino, A.; Hoffman, C.; Badal, K.; Garcia, B. A.; Callahan, M. K.; Yuan, J.; Martins, V. R.; Skog, J.; Kaplan, R. N.; Brady, M. S.; et al. Melanoma Exosomes Educate Bone Marrow Progenitor Cells Toward a Pro-Metastatic Phenotype through MET. Nat. Med. 2012, 18, 883-891.

(24) Campanella, C.; Rappa, F.; Sciume, C.; Marino Gammazza, A.; Barone, R.; Bucchieri, F.; David, S.; Curcuru, G.; Caruso Bavisotto, C.; Pitruzzella, A.; Geraci, G.; Modica, G.; Farina, F.; Zummo, G.; Fais, S.; Conway de Macario, E.; Macario, A. J.; Cappello, F. Heat Shock Protein 60 Levels in Tissue and Circulating Exosomes in Human Large Bowel Cancer Before and After Ablative Surgery. Cancer 2015, 121, 3230-3239.

(25) Khan, S.; Jutzy, J. M.; Valenzuela, M. M.; Turay, D.; Aspe, J. R.; Ashok, A.; Mirshahidi, S.; Mercola, D.; Lilly, B.; Wall, N. R. PlasmaDerived Exosomal Survivin, A Plausible Biomarker for Early Detection of Prostate Cancer. PLoS One 2012, 7, e46737.

(26) Nawaz, M.; Camussi, G.; Valadi, H.; Nazarenko, I.; Ekstrom, K.; Wang, X. Q.; Principe, S.; Shah, N.; Ashraf, M.; Fatima, F.; Neder, L.; Kislinger, T. The Emerging Role of Extracellular Vesicles as Biomarkers for Urogenital Cancers. Nat. Rev. Urol. 2014, 11, 688-701.

(27) Nyalwidhe, J. O.; Betesh, L. R.; Powers, T. W.; Jones, E. E.; White, K. Y.; Burch, T. C.; Brooks, J.; Watson, M. T.; Lance, R. S.; Troyer, D. A.; Semmes, O. J.; Mehta, A.; Drake, R. R. Increased Bisecting N-Acetylglucosamine and Decreased Branched Chain Glycans of N-Linked Glycoproteins in Expressed Prostatic Secretions Associated with Prostate Cancer Progression. Proteomics: Clin. Appl. 2013, 7, 677-689.

(28) Tokuhisa, M.; Ichikawa, Y.; Kosaka, N.; Ochiya, T.; Yashiro, M.; Hirakawa, K.; Kosaka, T.; Makino, H.; Akiyama, H.; Kunisaki, C.; Endo, I. Exosomal miRNAs from Peritoneum Lavage Fluid as Potential Prognostic Biomarkers of Peritoneal Metastasis in Gastric Cancer. PLoS One 2015, 10, e0130472.

(29) Admyre, C.; Grunewald, J.; Thyberg, J.; Gripenback, S.; Tornling, G.; Eklund, A.; Scheynius, A.; Gabrielsson, S. Exosomes with Major Histocompatibility Complex Class II and Co-Stimulatory Molecules are Present in Human BAL Fluid. Eur. Respir. J. 2003, 22, $578-583$.

(30) Qazi, K. R.; Torregrosa Paredes, P.; Dahlberg, B.; Grunewald, J.; Eklund, A.; Gabrielsson, S. Proinflammatory Exosomes in Bronchoalveolar Lavage Fluid of Patients with Sarcoidosis. Thorax 2010, 65, $1016-1024$.

(31) Levanen, B.; Bhakta, N. R.; Torregrosa Paredes, P.; Barbeau, R.; Hiltbrunner, S.; Pollack, J. L.; Skold, C. M.; Svartengren, M.; Grunewald, J.; Gabrielsson, S.; Eklund, A.; Larsson, B. M.; Woodruff, P. G.; Erle, D. J.; Wheelock, A. M. Altered MicroRNA Profiles in Bronchoalveolar Lavage Fluid Exosomes in Asthmatic Patients. I. Allergy Clin. Immunol. 2013, 131, 894-903.

(32) Rodriguez, M.; Silva, J.; Lopez-Alfonso, A.; Lopez-Muniz, M. B.; Pena, C.; Dominguez, G.; Garcia, J. M.; Lopez-Gonzalez, A.; Mendez, M.; Provencio, M.; Garcia, V.; Bonilla, F. Different Exosome Cargo from Plasma/Bronchoalveolar Lavage in Non-Small-Cell Lung Cancer. Genes, Chromosomes Cancer 2014, 53, 713-724.

(33) Lasser, C.; O’Neil, S. E.; Ekerljung, L.; Ekstrom, K.; Sjostrand, M.; Lotvall, J. RNA-Containing Exosomes in Human Nasal Secretions. Am. I. Rhinol. Allergy 2011, 25, 89-93.

(34) Pocsfalvi, G.; Stanly, C.; Vilasi, A.; Fiume, I.; Tatè, R.; Capasso, G. Employing Extracellular Vesicles for Non-Invasive Renal Monitoring: A Captivating Prospect. World I. Clin. Urol. 2014, 3, 66-80.

(35) Gamez-Valero, A.; Lozano-Ramos, S. I.; Bancu, I.; LauzuricaValdemoros, R.; Borras, F. E. Urinary Extracellular Vesicles as Source of Biomarkers in Kidney Diseases. Front. Immunol. 2015, 6, 6. 
(36) Lozano-Ramos, I.; Bancu, I.; Oliveira-Tercero, A.; Armengol, M. P.; Menezes-Neto, A.; Del Portillo, H. A.; Lauzurica-Valdemoros, R.; Borras, F. E. Size-Exclusion Chromatography-Based Enrichment of Extracellular Vesicles from Urine Samples. J. Extracell. Vesicles 2015, 4, 27369.

(37) Miranda, K. C.; Bond, D. T.; Levin, J. Z.; Adiconis, X.; Sivachenko, A.; Russ, C.; Brown, D.; Nusbaum, C.; Russo, L. M. Massively Parallel Sequencing of Human Urinary Exosome/Microvesicle RNA Reveals a Predominance of Non-Coding RNA. PLoS One 2014, 9, e96094.

(38) Moon, P. G.; Lee, J. E.; You, S.; Kim, T. K.; Cho, J. H.; Kim, I. S.; Kwon, T. H.; Kim, C. D.; Park, S. H.; Hwang, D.; Kim, Y. L.; Baek, M. C. Proteomic Analysis of Urinary Exosomes from Patients of Early IgA Nephropathy and Thin Basement Membrane Nephropathy. Proteomics 2011, 11, 2459-2475.

(39) Sáenz-Cuesta, M.; Arbelaiz, A.; Oregi, A.; Irizar, H.; OsorioQuerejeta, I.; Muñoz-Culla, M.; Banales, J. M.; Falcón-Pérez, J. M.; Olascoaga, J.; Otaegui, D. Methods for Extracellular Vesicles Isolation in a Hospital Setting. Front. Immunol. 2015, 6, 50.

(40) Budnik, V.; Ruiz-Canada, C.; Wendler, F. Extracellular Vesicles round off Communication in the Nervous System. Nat. Rev. Neurosci. 2016, 17, 160-172.

(41) Chen, Y.; Xiao, Y.; Lin, Z.; Xiao, X.; He, C.; Bihl, J. C.; Zhao, B.; Ma, X.; Chen, Y. J. The Role of Circulating Platelets Microparticles and Platelet Parameters in Acute Ischemic Stroke Patients. Stroke Cerebrovasc Dis. 2015, 24, 2313-2320.

(42) Rajendran, L.; Honsho, M.; Zahn, T. R.; Keller, P.; Geiger, K. D.; Verkade, P.; Simons, K. Alzheimer's Disease Beta-Amyloid Peptides are Released in Association with Exosomes. Proc. Natl. Acad. Sci. U. S. A. 2006, 103, 11172-11177.

(43) Joshi, P.; Benussi, L.; Furlan, R.; Ghidoni, R.; Verderio, C. Extracellular Vesicles in Alzheimer's Disease: Friends or Foes? Focus on Abeta-Vesicle Interaction. Int. I. Mol. Sci. 2015, 16, 4800-4813.

(44) Yuyama, K.; Sun, H.; Mitsutake, S.; Igarashi, Y. SphingolipidModulated Exosome Secretion Promotes Clearance of Amyloid-Beta by Microglia. I. Biol. Chem. 2012, 287, 10977-10989.

(45) Yuyama, K.; Sun, H.; Sakai, S.; Mitsutake, S.; Okada, M.; Tahara, H.; Furukawa, J.; Fujitani, N.; Shinohara, Y.; Igarashi, Y. Decreased Amyloid-Beta Pathologies by Intracerebral Loading of Glycosphingolipid-Enriched Exosomes in Alzheimer Model Mice. J. Biol. Chem. 2014, 289, 24488-24498.

(46) Agosta, F.; Dalla Libera, D.; Spinelli, E. G.; Finardi, A.; Canu, E.; Bergami, A.; Bocchio Chiavetto, L.; Baronio, M.; Comi, G.; Martino, G.; Matteoli, M.; Magnani, G.; Verderio, C.; Furlan, R. Myeloid Microvesicles in Cerebrospinal Fluid are Associated with Myelin Damage and Neuronal Loss in Mild Cognitive Impairment and Alzheimer Disease. Ann. Neurol. 2014, 76, 813-825.

(47) Verderio, C.; Muzio, L.; Turola, E.; Bergami, A.; Novellino, L.; Ruffini, F.; Riganti, L.; Corradini, I.; Francolini, M.; Garzetti, L.; Maiorino, C.; Servida, F.; Vercelli, A.; Rocca, M.; Dalla Libera, D.; Martinelli, V.; Comi, G.; Martino, G.; Matteoli, M.; Furlan, R. Myeloid Microvesicles are a Marker and Therapeutic Target for Neuroinflammation. Ann. Neurol. 2012, 72, 610-624.

(48) Shao, H.; Chung, J.; Balaj, L.; Charest, A.; Bigner, D. D.; Carter, B. S.; Hochberg, F. H.; Breakefield, X. O.; Weissleder, R; Lee, H. Protein Typing of Circulating Microvesicles Allows Real-Time Monitoring of Glioblastoma Therapy. Nat. Med. 2012, 18, 1835-1840. (49) Schwab, A.; Meyering, S. S.; Lepene, B.; Iordanskiy, S.; van Hoek, M. L.; Hakami, R. M.; Kashanchi, F. Extracellular Vesicles from Infected Cells: Potential for Direct Pathogenesis. Front. Microbiol. 2015, 6, 1132.

(50) Marcilla, A.; Martin-Jaular, L.; Trelis, M.; de Menezes-Neto, A.; Osuna, A.; Bernal, D.; Fernandez-Becerra, C.; Almeida, I. C.; Del Portillo, H. A. Extracellular Vesicles in Parasitic Diseases. J. Extracell. Vesicles 2014, 3, 25040.

(51) McDonald, M. K.; Tian, Y.; Qureshi, R. A.; Gormley, M.; Ertel, A.; Gao, R.; Aradillas Lopez, E.; Alexander, G. M.; Sacan, A.; Fortina, P.; Ajit, S. K. Functional Significance of Macrophage-Derived Exosomes in Inflammation and Pain. Pain 2014, 155, 1527-1539.
(52) Delabranche, X.; Berger, A.; Boisrame-Helms, J.; Meziani, F. Microparticles and Infectious Diseases. Med. Mal. Infect. 2012, 42, 335-343.

(53) Santarem, N.; Racine, G.; Silvestre, R.; Cordeiro-da-Silva, A.; Ouellette, M. Exoproteome Dynamics in Leishmania infantum. $J$. Proteomics 2013, 84, 106-118.

(54) Atayde, V. D.; Aslan, H.; Townsend, S.; Hassani, K.; Kamhawi, S.; Olivier, M. Exosome Secretion by the Parasitic Protozoan Leishmania within the Sand Fly Midgut. Cell Rep. 2015, 13, 957-967.

(55) Direskeneli, H. Autoimmunity vs Autoinflammation in Behcet's Disease: Do We Oversimplify a Complex Disorder? Rheumatology 2006, 45, 1461-1465.

(56) Raizman, M. B.; Foster, C. S. Plasma Exchange in the Therapy of Behcet's Disease. Graefe's Arch. Clin. Exp. Ophthalmol. 1989, 227, 360-363.

(57) Staubach, S.; Schadewaldt, P.; Wendel, U.; Nohroudi, K.; Hanisch, F. G. Differential Glycomics of Epithelial Membrane Glycoproteins from Urinary Exovesicles Reveals Shifts Toward Complex-Type N-Glycosylation in Classical Galactosemia. J. Proteome Res. 2012, 11, 906-916.

(58) Gerlach, J. Q.; Kilcoyne, M.; Farrell, M. P.; Kane, M.; Joshi, L. Differential Release of High Mannose Structural Isoforms by Fungal and Bacterial Endo-Beta-N-Acetylglucosaminidases. Mol. BioSyst. 2012, 8, 1472-1481.

(59) Raposo, G.; Nijman, H. W.; Stoorvogel, W.; Liejendekker, R.; Harding, C. V.; Melief, C. J.; Geuze, H. J. B Lymphocytes Secrete Antigen-Presenting Vesicles. I. Exp. Med. 1996, 183, 1161-1172.

(60) Zitvogel, L.; Regnault, A.; Lozier, A.; Wolfers, J.; Flament, C.; Tenza, D.; Ricciardi-Castagnoli, P.; Raposo, G.; Amigorena, S. Eradication of Established Murine Tumors Using a Novel Cell-Free Vaccine: Dendritic Cell-Derived Exosomes. Nat. Med. 1998, 4, 594600.

(61) Escudier, B.; Dorval, T.; Chaput, N.; Andre, F.; Caby, M. P.; Novault, S.; Flament, C.; Leboulaire, C.; Borg, C.; Amigorena, S.; Boccaccio, C.; Bonnerot, C.; Dhellin, O.; Movassagh, M.; Piperno, S.; Robert, C.; Serra, V.; Valente, N.; Le Pecq, J. B.; Spatz, A.; et al. Vaccination of Metastatic Melanoma Patients with Autologous Dendritic Cell (DC) Derived-Exosomes: Results of the First Phase I Clinical Trial. J. Transl. Med. 2005, 3, 10.

(62) Morse, M. A.; Garst, J.; Osada, T.; Khan, S.; Hobeika, A.; Clay, T. M.; Valente, N.; Shreeniwas, R.; Sutton, M. A.; Delcayre, A.; Hsu, D. H.; Le Pecq, J. B.; Lyerly, H. K. A Phase I Study of Dexosome Immunotherapy in Patients with Advanced Non-Small Cell Lung Cancer. I. Transl. Med. 2005, 3, 9.

(63) Viaud, S.; Ploix, S.; Lapierre, V.; Thery, C.; Commere, P. H.; Tramalloni, D.; Gorrichon, K.; Virault-Rocroy, P.; Tursz, T.; Lantz, O.; Zitvogel, L.; Chaput, N. Updated Technology To Produce Highly Immunogenic Dendritic Cell- Derived Exosomes of Clinical Grade: A Critical Role of Interferon-Gamma. J. Immunother. 2011, 34, 65-75.

(64) Besse, B.; Charrier, M.; Lapierre, V.; Dansin, E.; Lantz, O.; Planchard, D.; Le Chevalier, T.; Livartoski, A.; Barlesi, F.; Laplanche, A.; Ploix, S.; Vimond, N.; Peguillet, I.; Théry, C.; Lacroix, L.; Zoernig, I.; Dhodapkar, K.; Dhodapkar, M.; Viaud, S.; Soria, J.-C.; et al. Dendritic Cell-Derived Exosomes as Maintenance Immunotherapy after First Line Chemotherapy in NSCLC. Oncoimmunology 2015, 00.

(65) Aline, F.; Bout, D.; Amigorena, S.; Roingeard, P.; DimierPoisson, I. Toxoplasma gondii Antigen-Pulsed- Dendritic Cell-Derived Exosomes Induce a Protective Immune Response Against T. gondii Infection. Infect. Immun. 2004, 72, 4127-4137.

(66) Beauvillain, C.; Ruiz, S.; Guiton, R.; Bout, D.; Dimier-Poisson, I. A Vaccine Based on Exosomes Secreted by a Dendritic Cell Line Confers Protection Against T. gondii Infection in Syngeneic and Allogeneic Mice. Microbes Infect. 2007, 9, 1614-1622.

(67) Beauvillain, C.; Juste, M. O.; Dion, S.; Pierre, J.; Dimier-Poisson, I. Exosomes are an Effective Vaccine against Congenital Toxoplasmosis in Mice. Vaccine 2009, 27, 1750-1757.

(68) Martin-Jaular, L.; Nakayasu, E. S.; Ferrer, M.; Almeida, I. C.; del Portillo, H. A. Exosomes from Plasmodium yoelii-Infected 
Reticulocytes Protect Mice from Lethal Infections. PLoS One 2011, 6, e26588.

(69) Campos, J. H.; Soares, R. P.; Ribeiro, K.; Andrade, A. C.; Batista, W. L.; Torrecilhas, A. C. Extracellular Vesicles: Role in Inflammatory Responses and Potential Uses in Vaccination in Cancer and Infectious Diseases. I. Immunol. Res. 2015, 2015, 832057.

(70) Kulp, A.; Kuehn, M. J. Biological Functions and Biogenesis of Secreted Bacterial Outer Membrane Vesicles. Annu. Rev. Microbiol. 2010, 64, 163-184.

(71) Kaparakis-Liaskos, M.; Ferrero, R. L. Immune Modulation by Bacterial Outer Membrane Vesicles. Nat. Rev. Immunol. 2015, 15, 375-387.

(72) Holst, J.; Martin, D.; Arnold, R.; Huergo, C. C.; Oster, P.; O'Hallahan, J.; Rosenqvist, E. Properties and Clinical Performance of Vaccines Containing Outer Membrane Vesicles from. Vaccine 2009, 27, B3-12.

(73) Carter, N. J. Multicomponent Meningococcal Serogroup B Vaccine (4CMenB; Bexsero((R))): A Review of its Use in Primary and Booster Vaccination. BioDrugs 2013, 27, 263-274.

(74) Dai, S.; Wei, D.; Wu, Z.; Zhou, X.; Wei, X.; Huang, H.; Li, G. Phase I Clinical Trial of Autologous Ascites- Derived Exosomes Combined with GM-CSF for Colorectal Cancer. Mol. Ther. 2008, 16, $782-790$.

(75) Heldring, N.; Mager, I.; Wood, M. J.; Le Blanc, K.; Andaloussi, S. E. Therapeutic Potential of Multipotent Mesenchymal Stromal Cells and their Extracellular Vesicles. Hum. Gene Ther. 2015, 26, 506-517.

(76) Kordelas, L.; Rebmann, V.; Ludwig, A. K.; Radtke, S.; Ruesing, J.; Doeppner, T. R.; Epple, M.; Horn, P. A.; Beelen, D. W.; Giebel, B. MSC-Derived Exosomes: A Novel Tool To Treat Therapy-Refractory Graft-Versus-Host Disease. Leukemia 2014, 28, 970-973.

(77) Lai, R. C.; Yeo, R. W.; Lim, S. K. Mesenchymal Stem Cell Exosomes. Semin. Cell Dev. Biol. 2015, 40, 82-88.

(78) Bruno, S.; Deregibus, M. C.; Camussi, G. The Secretome of Mesenchymal Stromal Cells: Role of Extracellular Vesicles in Immunomodulation. Immunol. Lett. 2015, 168, 154-158.

(79) Bruno, S.; Grange, C.; Deregibus, M. C.; Calogero, R. A.; Saviozzi, S.; Collino, F.; Morando, L.; Busca, A.; Falda, M.; Bussolati, B.; Tetta, C.; Camussi, G. Mesenchymal Stem Cell-Derived Microvesicles Protect Against Acute Tubular Injury. J. Am. Soc. Nephrol. 2009, 20, 1053-1067.

(80) Doeppner, T. R.; Herz, J.; Gorgens, A.; Schlechter, J.; Ludwig, A. K.; Radtke, S.; de Miroschedji, K.; Horn, P. A.; Giebel, B.; Hermann, D. M. Extracellular Vesicles Improve Post-Stroke Neuroregeneration and Prevent Postischemic Immunosuppression. Stem Cells Transl. Med. 2015, 4, 1131-1143.

(81) Quesenberry, P. J.; Aliotta, J.; Deregibus, M. C.; Camussi, G. Role of Extracellular RNA-Carrying Vesicles in Cell Differentiation and Reprogramming. Stem Cell Res. Ther. 2015, 6, 153.

(82) Deregibus, M. C.; Cantaluppi, V.; Calogero, R.; Lo Iacono, M.; Tetta, C.; Biancone, L.; Bruno, S.; Bussolati, B.; Camussi, G. Endothelial Progenitor Cell Derived Microvesicles Activate an Angiogenic Program in Endothelial Cells by a Horizontal Transfer of mRNA. Blood 2007, 110, 2440-2448.

(83) Ranghino, A.; Cantaluppi, V.; Grange, C.; Vitillo, L.; Fop, F.; Biancone, L.; Deregibus, M. C.; Tetta, C.; Segoloni, G. P.; Camussi, G. Endothelial Progenitor Cell-Derived Microvesicles Improve Neovascularization in a Murine Model of Hindlimb Ischemia. Int. J. Immunopathol. Pharmacol. 2012, 25, 75-85.

(84) Cantaluppi, V.; Gatti, S.; Medica, D.; Figliolini, F.; Bruno, S.; Deregibus, M. C.; Sordi, A.; Biancone, L.; Tetta, C.; Camussi, G. Microvesicles Derived from Endothelial Progenitor Cells Protect the Kidney from Ischemia- Reperfusion Injury by MicroRNA-Dependent Reprogramming of Resident Renal Cells. Kidney Int. 2012, 82, 412427.

(85) Smyth, L. A.; Ratnasothy, K.; Tsang, J. Y.; Boardman, D.; Warley, A.; Lechler, R.; Lombardi, G. CD73 Expression on Extracellular Vesicles Derived from CD4+ CD25+ Foxp3+ T Cells Contributes to their Regulatory Function. Eur. J. Immunol. 2013, 43, $2430-2440$.
(86) Xie, Y.; Zhang, X.; Zhao, T.; Li, W.; Xiang, J. Natural CD8(+)25(+) Regulatory $\mathrm{T}$ Cell-Secreted Exosomes Capable of Suppressing Cytotoxic T Lymphocyte-Mediated Immunity Against B16 Melanoma. Biochem. Biophvs. Res. Commun. 2013, 438, 152-155.

(87) Okoye, I. S.; Coomes, S. M.; Pelly, V. S.; Czieso, S.; Papayannopoulos, V.; Tolmachova, T.; Seabra, M. C.; Wilson, M. S. MicroRNA-Containing T-Regulatory-Cell-Derived Exosomes Suppress Pathogenic T Helper 1 Cells. Immunity 2014, 41, 89-103.

(88) Montaner, S.; Galiano, A.; Trelis, M.; Martin-Jaular, L.; Del Portillo, H. A.; Bernal, D.; Marcilla, A. The Role of Extracellular Vesicles in Modulating the Host Immune Response during Parasitic Infections. Front. Immunol. 2014, 5, 433.

(89) Buck, A. H.; Coakley, G.; Simbari, F.; McSorley, H. J.; Quintana, J. F.; Le Bihan, T.; Kumar, S.; Abreu- Goodger, C.; Lear, M.; Harcus, Y.; Ceroni, A.; Babayan, S. A.; Blaxter, M.; Ivens, A.; Maizels, R. M. Exosomes Secreted by Nematode Parasites Transfer Small RNAs to Mammalian Cells and Modulate Innate Immunity. Nat. Commun. 2014, 5, 5488.

(90) Nikanjam, M.; Blakely, E. A.; Bjornstad, K. A.; Shu, X.; Budinger, T. F.; Forte, T. M. Synthetic Nano-Low Density Lipoprotein as Targeted Drug Delivery Vehicle for Glioblastoma Multiforme. Int. I. Pharm. 2007, 328, 86-94.

(91) Corbin, I. R; Zheng, G. Mimicking Nature's Nanocarrier: Synthetic Low-Density Lipoprotein-Like Nanoparticles for CancerDrug Delivery. Nanomedicine 2007, 2, 375-380.

(92) Roberts, T. C.; Ezzat, K.; El Andaloussi, S.; Weinberg, M. S. Synthetic SiRNA Delivery: Progress and Prospects. Methods Mol. Biol. 2016, 1364, 291-310.

(93) Saari, H.; Lazaro-Ibanez, E.; Viitala, T.; Vuorimaa-Laukkanen, E.; Siljander, P.; Yliperttula, M. Microvesicle- and Exosome-Mediated Drug Delivery Enhances the Cytotoxicity of Paclitaxel in Autologous Prostate Cancer Cells. I. Controlled Release 2015, 220, 727-737.

(94) El Andaloussi, S.; Mager, I.; Breakefield, X. O.; Wood, M. J. Extracellular Vesicles: Biology and Emerging Therapeutic Opportunities. Nat. Rev. Drug Discovery 2013, 12, 347-357.

(95) Lazaro-Ibanez, E.; Sanz-Garcia, A.; Visakorpi, T.; EscobedoLucea, C.; Siljander, P.; Ayuso-Sacido, A.; Yliperttula, M. Different gDNA Content in the Subpopulations of Prostate Cancer Extracellular Vesicles: Apoptotic Bodies, Microvesicles, and Exosomes. Prostate 2014, 74, 1379-1390.

(96) Thakur, B. K.; Zhang, H.; Becker, A.; Matei, I.; Huang, Y.; Costa-Silva, B.; Zheng, Y.; Hoshino, A.; Brazier, H.; Xiang, J.; et al. Double-stranded DNA in exosomes: a novel biomarker in cancer detection. Cell Res. 2014, 24, 766-769.

(97) O’Brien, K.; Lowry, M. C.; Corcoran, C.; Martinez, V. G.; Daly, M.; Rani, S.; Gallagher, W. M.; Radomski, M. W.; MacLeod, R. A.; O’Driscoll, L. miR-134 in Extracellular Vesicles Reduces TripleNegative Breast Cancer Aggression and Increases Drug Sensitivity. Oncotarget 2015, 6, 32774-32789.

(98) Haney, M. J.; Klyachko, N. L.; Zhao, Y. L.; Gupta, R.; Plotnikova, E. G.; He, Z. J.; Patel, T.; Piroyan, A.; Sokolsky, M.; Kabanov, A. V.; Batrakova, E. V. Exosomes as Drug Delivery Vehicles for Parkinson's Disease Therapy. I. Controlled Release 2015, 207, 18 30.

(99) EL Andaloussi, S.; Lakhal, S.; Mager, I.; Wood, M. J. A. Exosomes for Targeted siRNA Delivery Across Biological Barriers. Adv. Drug Deliverv Rev. 2013, 65, 391-397.

(100) Cooper, J. M.; Wiklander, P. B.; Nordin, J. Z.; Al-Shawi, R.; Wood, M. J.; Vithlani, M.; Schapira, A. H.; Simons, J. P.; El-Andaloussi, S.; Alvarez-Erviti, L. Systemic Exosomal siRNA Delivery Reduced Alpha-Synuclein Aggregates in Brains of Transgenic Mice. Mov. Disord. 2014, 29, 1476-1485.

(101) Kooijmans, S. A.; Stremersch, S.; Braeckmans, K.; de Smedt, S. C.; Hendrix, A.; Wood, M. J.; Schiffelers, R. M.; Raemdonck, K.; Vader, P. Electroporation-Induced siRNA Precipitation Obscures the Efficiency of siRNA Loading into Extracellular Vesicles. J. Controlled Release 2013, 172, 229-238.

(102) Roberts, T. C.; Godfrey, C.; McClorey, G.; Vader, P.; Briggs, D.; Gardiner, C.; Aoki, Y.; Sargent, I.; Morgan, J. E.; Wood, M. J. 
Extracellular MicroRNAs are Dynamic Non-Vesicular Biomarkers of Muscle Turnover. Nucleic Acids Res. 2013, 41, 9500-9513.

(103) Jang, S. C.; Kim, O. Y.; Yoon, C. M.; Choi, D. S.; Roh, T. Y.; Park, J.; Nilsson, J.; Lotvall, J.; Kim, Y. K.; Gho, Y. S. Bioinspired Exosome-Mimetic Nanovesicles for Targeted Delivery of Chemotherapeutics to Malignant Tumors. ACS Nano 2013, 7, 7698-7710.

(104) Kooijmans, S. A. A.; Vader, P.; van Dommelen, S. M.; van Solinge, W. W.; Schiffelers, R. M. Exosome Mimetics: A Novel Class of Drug Delivery Systems. Int. I. Nanomed. 2012, 7, 1525-1541.

(105) Lakhal, S.; Wood, M. J. Exosome Nanotechnology: An Emerging Paradigm Shift in Drug Delivery: Exploitation of Exosome Nanovesicles for Systemic in vivo Delivery of RNAi Heralds New Horizons for Drug Delivery Across Biological Barriers. BioEssays 2011, 33, 737-741.

(106) van Niel, G.; Bergam, P.; Di Cicco, A.; Hurbain, I.; Lo Cicero, A.; Dingli, F.; Palmulli, R.; Fort, C.; Potier, M. C.; Schurgers, L. J.; Loew, D.; Levy, D.; Raposo, G. Apolipoprotein E Regulates Amyloid Formation within Endosomes of Pigment Cells. Cell Rep. 2015, 13, $43-51$.

(107) Knop, K.; Hoogenboom, R.; Fischer, D.; Schubert, U. S. Poly(ethylene glycol) in Drug Delivery: Pros and Cons as well as Potential Alternatives. Ancew. Chem. Int. Ed. 2010, 49, 6288-6308.

(108) Schroeder, A.; Heller, D. A.; Winslow, M. M.; Dahlman, J. E.; Pratt, G. W.; Langer, R.; Jacks, T.; Anderson, D. G. Treating Metastatic Cancer with Nanotechnology. Nat. Rev. Cancer 2012, 12, $39-50$.

(109) Hu, C. M.; Zhang, L.; Aryal, S.; Cheung, C.; Fang, R. H.; Zhang, L. Erythrocyte Membrane-Camouflaged Polymeric Nanoparticles as a Biomimetic Delivery Platform. Proc. Natl. Acad. Sci. U. S. A. 2011, 108, 10980-10985.

(110) Fang, R. H.; Hu, C. M.; Luk, B. T.; Gao, W.; Copp, J. A.; Tai, Y.; O'Connor, D. E.; Zhang, L. Cancer Cell Membrane-Coated Nanoparticles for Anticancer Vaccination and Drug Delivery. Nano Lett. 2014, 14, 2181-2188.

(111) Parodi, A.; Quattrocchi, N.; van de Ven, A. L.; Chiappini, C.; Evangelopoulos, M.; Martinez, J. O.; Brown, B. S.; Khaled, S. Z.; Yazdi, I. K.; Enzo, M. V.; Isenhart, L.; Ferrari, M.; Tasciotti, E. Synthetic Nanoparticles Functionalized with Biomimetic Leukocyte Membranes Possess Cell-Like Functions. Nat. Nanotechnol. 2013, 8, 61-68.

(112) Zonneveld, M. I.; Brisson, A. R.; van Herwijnen, M. J.; Tan, S.; van de Lest, C. H.; Redegeld, F. A.; Garssen, J.; Wauben, M. H.; Nolte't Hoen, E. N. Recovery of Extracellular Vesicles from Human Breast Milk is Influenced by Sample Collection and Vesicle Isolation Procedures. J. Extracell. Vesicles 2014, 3, 24215.

(113) Lasser, C.; Alikhani, V. S.; Ekstrom, K.; Eldh, M.; Paredes, P. T.; Bossios, A.; Sjostrand, M.; Gabrielsson, S.; Lotvall, J.; Valadi, H. Human Saliva, Plasma and Breast Milk Exosomes Contain RNA: Uptake by Macrophages. I. Transl. Med. 2011, 9, 9.

(114) Batista, B. S.; Eng, W. S.; Pilobello, K. T.; Hendricks-Munoz, K. D.; Mahal, L. K. Identification of a Conserved Glycan Signature for Microvesicles. I. Proteome Res. 2011, 10, 4624-4633.

(115) Hung, M. E.; Leonard, J. N. Stabilization of ExosomeTargeting Peptides via Engineered Glycosylation. J. Biol. Chem. 2015, 290, 8166-8172.

(116) Marleau, A. M.; Chen, C. S.; Joyce, J. A.; Tullis, R. H. Exosome Removal as a Therapeutic Adjuvant in Cancer. J. Transl. Med. 2012, $10,134$.

(117) Lo Cicero, A.; Stahl, P. D.; Raposo, G. Extracellular Vesicles Shuffling Intercellular Messages: For Good or For Bad. Curr. Opin. Cell Biol. 2015, 35, 69-77.

(118) Flanagan, J.; Middeldorp, J.; Sculley, T. Localization of the Epstein-Barr Virus Protein LMP 1 to Exosomes. J. Gen. Virol. 2003, 84, $1871-1879$.

(119) Canitano, A.; Venturi, G.; Borghi, M.; Ammendolia, M. G.; Fais, S. Exosomes Released in vitro from Epstein- Barr Virus (EBV)Infected Cells Contain EBV-Encoded Latent Phase mRNAs. Cancer Lett. 2013, 337, 193-199.

(120) Haneklaus, M.; Gerlic, M.; Kurowska-Stolarska, M.; Rainey, A. A.; Pich, D.; McInnes, I. B.; Hammerschmidt, W.; O’Neill, L. A.;
Masters, S. L. Cutting Edge: miR-223 and EBV miR-BART15 Regulate the NLRP3 Inflammasome and IL-1beta Production. J. Immunol. 2012, 189, 3795-3799.

(121) Narayanan, A.; Iordanskiy, S.; Das, R.; Van Duyne, R.; Santos, S.; Jaworski, E.; Guendel, I.; Sampey, G.; Dalby, E.; Iglesias-Ussel, M.; Popratiloff, A.; Hakami, R.; Kehn-Hall, K.; Young, M.; Subra, C.; Gilbert, C.; Bailey, C.; Romerio, F.; Kashanchi, F. Exosomes Derived from HIV-1-Infected Cells Contain Trans-Activation Response Element RNA. L. Biol. Chem. 2013, 288, 20014-20033.

(122) Dreux, M.; Garaigorta, U.; Boyd, B.; Decembre, E.; Chung, J.; Whitten-Bauer, C.; Wieland, S.; Chisari, F. V. Short-Range Exosomal Transfer of Viral RNA from Infected Cells to Plasmacytoid Dendritic Cells Triggers Innate Immunity. Cell Host Microbe 2012, 12, 558-570.

(123) Nour, A. M.; Modis, Y. Endosomal Vesicles as Vehicles for Viral Genomes. Trends Cell Biol. 2014, 24, 449-454.

(124) Izquierdo-Useros, N.; Naranjo-Gomez, M.; Archer, J.; Hatch, S. C.; Erkizia, I.; Blanco, J.; Borras, F. E.; Puertas, M. C.; Connor, J. H.; Fernandez-Figueras, M. T.; Moore, L.; Clotet, B.; Gummuluru, S.; Martinez-Picado, J. Capture and Transfer of HIV-1 Particles by Mature Dendritic Cells Converges with the Exosome-Dissemination Pathway. Blood 2009, 113, 2732-2741.

(125) Properzi, F.; Logozzi, M.; Abdel-Haq, H.; Federici, C.; Lugini, L.; Azzarito, T.; Cristofaro, I.; di Sevo, D.; Ferroni, E.; Cardone, F.; Venditti, M.; Colone, M.; Comoy, E.; Durand, V.; Fais, S.; Pocchiari, M. Detection of Exosomal Prions in Blood by Immunochemistry Techniques. I. Gen. Virol. 2015, 96, 1969-1974.

(126) Fevrier, B.; Vilette, D.; Laude, H.; Raposo, G. Exosomes: A Bubble Ride for Prions? Traffic 2005, 6, 10-17.

(127) Fevrier, B.; Vilette, D.; Archer, F.; Loew, D.; Faigle, W.; Vidal, M.; Laude, H.; Raposo, G. Cells Release Prions in Association with Exosomes. Proc. Natl. Acad. Sci. U. S. A. 2004, 101, 9683-9688.

(128) Coleman, B. M.; Hill, A. F. Extracellular Vesicles - Their Role in the Packaging and Spread of Misfolded Proteins Associated with Neurodegenerative Diseases. Semin. Cell Dev. Biol. 2015, 40, 89-96.

(129) Saa, P.; Yakovleva, O.; de Castro, J.; Vasilyeva, I.; De Paoli, S. H.; Simak, J.; Cervenakova, L. First Demonstration of Transmissible Spongiform Encephalopathy-Associated Prion Protein (PrPTSE) in Extracellular Vesicles from Plasma of Mice Infected with MouseAdapted Variant Creutzfeldt-Jakob Disease by in vitro Amplification. J. Biol. Chem. 2014, 289, 29247-29260.

(130) Zhuang, X.; Xiang, X.; Grizzle, W.; Sun, D.; Zhang, S.; Axtell, R. C.; Ju, S.; Mu, J.; Zhang, L.; Steinman, L.; Miller, D.; Zhang, H. G. Treatment of Brain Inflammatory Diseases by Delivering Exosome Encapsulated Anti- Inflammatory Drugs from the Nasal Region to the Brain. Mol. Ther. 2011, 19, 1769-1779.

(131) Federici, C.; Petrucci, F.; Caimi, S.; Cesolini, A.; Logozzi, M.; Borghi, M.; D’llio, S.; Lugini, L.; Violante, N.; Azzarito, T.; Majorani, C.; Brambilla, D.; Fais, S. Exosome Release and Low pH Belong to a Framework of Resistance of Human Melanoma Cells to Cisplatin. PLoS One 2014, 9, e88193.

(132) Lotvall, J.; Hill, A. F.; Hochberg, F.; Buzas, E. I.; Di Vizio, D.; Gardiner, C.; Gho, Y. S.; Kurochkin, I. V.; Mathivanan, S.; Quesenberry, P.; Sahoo, S.; Tahara, H.; Wauben, M. H.; Witwer, K. W.; Thery, C. Minimal Experimental Requirements for Definition of Extracellular Vesicles and their Functions: A Position Statement from the International Society for Extracellular Vesicles. J. Extracell. Vesicles 2014, 3, 26913.

(133) Witwer, K. W.; Buzas, E. I.; Bemis, L. T.; Bora, A.; Lasser, C.; Lotvall, J.; Nolte-'t Hoen, E. N.; Piper, M. G.; Sivaraman, S.; Skog, J.; Thery, C.; Wauben, M. H.; Hochberg, F. Standardization of Sample Collection, Isolation and Analysis Methods in Extracellular Vesicle Research. I. Extracell. Vesicles 2013, 2, 20360.

(134) Zarovni, N.; Corrado, A.; Guazzi, P.; Zocco, D.; Lari, E.; Radano, G.; Muhhina, J.; Fondelli, C.; Gavrilova, J.; Chiesi, A. Integrated Isolation and Quantitative Analysis of Exosome Shuttled Proteins and Nucleic Acids Using Immunocapture Approaches. Methods 2015, 87, 46-58.

(135) Mrvar-Brecko, A.; Sustar, V.; Jansa, V.; Stukelj, R.; Jansa, R.; Mujagic, E.; Kruljc, P.; Iglic, A.; Hagerstrand, H.; Kralj-Iglic, V. Isolated 
Microvesicles from Peripheral Blood and Body Fluids as observed by Scanning Electron Microscope. Blood Cells, Mol., Dis. 2010, 44, 307312.

(136) Sustar, V.; Bedina-Zavec, A.; Stukelj, R.; Frank, M.; Bobojevic, G.; Jansa, R.; Ogorevc, E.; Kruljc, P.; Mam, K.; Simunic, B.; et al. Nanoparticles isolated from Blood: a Reflection of Vesiculability of Blood Cells during the Isolation Process. Int. J. Nanomed. 2011, 6, 2737-2748.

(137) Skog, J.; Würdinger, T.; van Rijn, S.; Meijer, D. H.; Gainche, L.; Sena-Esteves, M.; et al. Glioblastoma microvesicles transport RNA and proteins that promote tumor growth and provide diagnostic biomarkers. Nat. Cell Biol. 2008, 10, 1470-1476.

(138) Skog, J.; Würdinger, T.; van Rijn, S.; Meijer, D. H.; Gainche, L.; Sena-Esteves, M.; et al. Glioblastoma microvesicles transport RNA and proteins that promote tumor growth and provide diagnostic biomarkers. Nat. Cell Biol. 2008, 10, 1470-1476.

(139) Yamashita, T.; Kamada, H.; Kanasaki, S.; Maeda, Y.; Nagano, K.; Abe, Y. Epidermal growth factor receptor localized to exosome membranes as a possible biomarker for lung cancer diagnosis. Pharmazie 2013, 68, 969-973.

(140) Taylor, D. D.; Gercel-Taylor, C. MicroRNA signatures of tumor-derived exosomes as diagnostic biomarkers of ovarian cancer. Gunecol Oncol 2008, 110, 13-21.

(141) Manerola, L.; Guruceaga, E.; Gallego Perez-Larraya, J. A small non coding RNA signature found in exosomes of GBM patient serum as a diagnostic tool. Neuro Onco. 2014, 16, 164-167.

(142) Ogata-Kawata, H.; Izumiya, M.; Kurioka, D.; Honma, Y.; Yamada, Y.; Furuta, K. Circulating exosomal microRNAs as biomarkers of colon cancer. PLoS One 2014, 9, e92921.

(143) Yoshida, Y.; Yamamoto, H.; Morita, R.; Oikawa, R.; Matsuo, Y.; Maehata, T.; Nosho, K.; Watanabe, Y.; Yasuda, H.; Itoh, F. Detection of DNA methylation of gastric juice-derived exosomes in gastric cancer. Integr. Mol. Med. 2014, 1, 17-21.

(144) Baran, J.; Baj-Krzyworzeka, M.; Weglarczyk, K.; Szatanek, R.; Zembala, M.; Barbasz, J. Circulating tumor-derived microvesicles in plasma of gastric cancer patients. Cancer Immunol Immunother 2010, 59, 841-850.

(145) Cazzoli, R.; Buttitta, F.; Di Nicola, M.; Malatesta, S.; Marchetti, A.; Rom, W. N. microRNAs derived from circulating exosomes as noninvasive biomarkers for screening and diagnosing lung cancer. $J$ Thorac Oncol 2013, 8, 1156-1162.

(146) Szajnik, M.; Derbis, M.; Lach, M.; Patalas, P.; Michalak, M.; Drzewiecka, H. Exosomes in plasma of patients with ovarian carcinoma: potential biomarkers of tumor progression and response to therapy. Gynecol. Obstet. 2013, 3.

(147) Que, R.; Ding, G.; Chen, J.; Cao, L. Analysis of serum exosomal microRNAs and clinicopathologic features of patients with pancreatic adenocarcinoma. World J SurgOncol 2013, 11, 219.

(148) Kahlert, C.; Melo, S. A.; Protopopov, A.; Tang, J.; Seth, S.; Koch, M. Identification of double-stranded genomic DNA spanning all chromosomes with mutated KRAS and p53 DNA in the serum exosomes of patients with pancreatic cancer. J Biol Chem 2014, 289, $3869-3875$.

(149) Raimondo, F.; Morosi, L.; Corbetta, S.; Chinello, C.; Brambilla, P.; Della Mina, P.; Villa, A.; Albo, G.; Battaglia, C.; Bosari, S.; Magni, F.; Pitto, M. Differential protein profiling of renal cell carcinoma urinary exosomes. Mol. BioSyst. 2013, 6, 1220-33.

(150) Beckham, C. J.; Olsen, J.; Yin, P. N.; Wu, C. H.; Ting, H. J.; Hagen, F. K.; Scosyrev, E.; Messing, E. M.; Lee, Y. F. Bladder cancer exosomes contain EDIL-3/Del1 and facilitate cancer progression. $J$ Urol. 2014, 192, 583-592.

(151) Perez, A.; Loizaga, A.; Arceo, R.; Lacasa, I.; Rabade, A.; Zorroza, K.; Mosen-Ansorena, D.; Gonzalez, E.; Aransay, A. M.; Falcon-Perez, J. M.; Unda-Urzaiz, M.; Royo, F. A Pilot Study on the Potential of RNA-Associated to Urinary Vesicles as a Suitable NonInvasive Source for Diagnostic Purposes in Bladder Cancer. Cancers (Basel) 2014, 6, 179-192.

(152) Chen, C. L.; Lai, Y. F.; Tang, P.; Chien, K. Y.; Yu, J. S.; Tsai, C. H.; Chen, H. W.; Wu, C. C.; Chung, T.; Hsu, C. W.; Chen, C. D.;
Chang, Y. S.; Chang, P. L.; Chen, Y. T. Comparative and targeted proteomic analyses of urinary microparticles from bladder cancer and hernia patients. I. Proteome Res. 2012, 11, 5611-5629.

(153) Bijnsdorp, I. V.; Geldof, A. A.; Lavaei, M.; Piersma, S. R.; van Moorselaar, R. J.; Jimenez, C. R. Exosomal ITGA3 interferes with noncancerous prostate cell functions and is increased in urine exosomes of metastatic prostate cancer patients. J Extracell Vesicles 2013, 2.

(154) Corcoran, C.; Rani, S.; O'Driscoll, L. miR-34a is an intracellular and exosomal predictive biomarker for response to docetaxel with clinical relevance to prostate cancer progression. Prostate 2014, 74, $1320-1334$

(155) Overbye, A.; Skotland, T.; Koehler, C. J.; Thiede, B.; Seierstad, T.; Berge, V.; Sandvig, K.; Llorente, A. Identification of prostate cancer biomarkers in urinary exosomes. Oncotarget 2015, 6, 30357-30376.

(156) Neeb, A.; Hefele, S.; Bormann, S.; Adams, F.; Wolf, P.; Miernik, A.; Schonthaler, M.; Krosnig, M.; Schulze-Seemann, W.; Nestel, S.; Bu, H.; Klocker, H.; Nazarenko, I.; Cato, A. Splice variant transcripts of anterior gradient 2 gene in urine exosomes as markers for prostate cancer detection. Oncotargets 2014, 5, 8681-8689. 